\title{
Carboranes as guests, counterions and linkers in coordination polymers and networks
}

Catherine E. Housecroft

Department of Chemistry, University of Basel, Spitalstrasse 51, 4056 Basel, Switzerland

E-mail: catherine.housecroft@unibas.ch

†This review is dedicated to Russ Grimes, a true pioneer in carborane (carborane) cluster chemistry, on the occasion of his 80th birthday.

\begin{abstract}
Carborane clusters play a variety of roles in the assembly of 1D-coordination polymers and 2D- and 3D-networks. In this review, comments on coordination polymers in which neutral carborane guests are accommodated are followed by discussion of the incorporation of anionic carboranes into coordination polymers and networks, with critical comments concerning the classification of some 'coordination polymers' within the 2013 IUPAC guidelines.

Functionalization of carborane clusters with carboxylato, phosphino or 2,2 ':6',2"-terpyridinyl domains provides potential for their incorporation as covalently bound linkers into the backbones of coordination polymers and frameworks; in the case of phosphino-functionalized clusters, the carborane clusters are located on the periphery of the 1D-polymer chains.
\end{abstract}

Keywords: Carborane; carbaborane; coordination polymer; network; MOF

\section{Introduction}

Russ Grimes has been active in the field of carborane chemistry since the 1960s and during this period, icosahedral $\mathrm{C}_{2} \mathrm{~B}_{10}$ and $\mathrm{CB}_{11}$-clusters have progressed from something of a geometrical oddity to being components in a huge number of materials with wide-ranging applications [1]. In this article, the interface between icosahedral carboranes and coordination polymers including metalorganic frameworks, MOFs [2], is reviewed. The roles of carborane clusters in 1D-coordination polymers [3] and 2D- and 3D-networks varies from their 
capture as guest molecules, to their incorporation as weakly coordinating anions, and to their functionalizion so they can act as linkers in the backbones of coordination polymers and nets.

All searches of the Cambridge Structural Database (CSD) made for this review used the CSD version 5.36 with updates to November 2014 [4] and Conquest v. 1.17 [5] and figures have been drawn using original data.

\section{Coordination polymers as hosts for carboranes}

The bowl-shaped molecule cyclotriveratrylene (CTV) is dimensionally compatible with an icosahedral carborane cage. The transition from simple hostguest assembly with discrete domains [6] to coordination polymer [7] is made by replacing neutral $1,2-\mathrm{C}_{2} \mathrm{~B}_{10} \mathrm{H}_{12}$ by a salt $\mathrm{M}\left[\mathrm{CB}_{11} \mathrm{H}_{12}\right](\mathrm{M}=\mathrm{Na}, \mathrm{K}, \mathrm{Rb}, \mathrm{Cs})$. However, the situation is not as straightforward as this statement suggests. A comparison of the structures of $\left\{\left[\mathrm{M}(\mathrm{CTV})_{2}(\mathrm{OH})\left(\mathrm{H}_{2} \mathrm{O}\right)_{2}\right] \cdot \mathrm{DMF} \cdot 1,2-\mathrm{C}_{2} \mathrm{~B}_{10} \mathrm{H}_{12}\right\}_{n}$ (formed from CTV, 1,2- $\mathrm{C}_{2} \mathrm{~B}_{10} \mathrm{H}_{12}$ and $\mathrm{MOH}$ with $\mathrm{M}=\mathrm{Cs}$ or $\mathrm{Rb}$ in DMF), $\left\{\left[\mathrm{Cs}(\mathrm{CTV})_{2}\left(\mathrm{H}_{2} \mathrm{O}\right)_{3}\right]\left[\mathrm{CB}_{11} \mathrm{H}_{12}\right] \cdot 2 \mathrm{DMF}\right\}_{n}$ (formed from CTV and $\mathrm{Cs}\left[\mathrm{CB}_{11} \mathrm{H}_{12}\right]$ ) and $\left\{\left[\mathrm{Rb}(\mathrm{CTV})_{2}\left(\mathrm{H}_{2} \mathrm{O}\right)_{3}\right]\left[\mathrm{CB}_{11} \mathrm{H}_{12}\right] \cdot 2 \mathrm{DMF}\right\}_{n}$ (formed from CTV and $\mathrm{Rb}\left[\mathrm{CB}_{11} \mathrm{H}_{12}\right]$ in the presence of $\mathrm{MOH}$ ) reveals similar features (Figure 1a); the structures are also similar to those of related systems containing $\mathrm{K}^{+}$and $\mathrm{Na}^{+}$ions. The authors [7] conclude that the carborane plays the same role whether it is neutral or anionic, and therefore steric factors are dominant. Functionalization of CTV with peripheral metal-binding domains (e.g. pyridyl groups, 1, Scheme 1) provides a 3-connecting linker. When combined with $\mathrm{Cd}(\mathrm{OAc})_{2}$, a $4.8^{2}$ net assembles (Figure 1b) which hosts 1,2- $\mathrm{C}_{2} \mathrm{~B}_{10} \mathrm{H}_{12}$ molecules within the bowl-shaped cavities of $\mathbf{1}$ (Figure 1c). In the absence of the carborane, the 2D-network is no longer formed. The authors [8] propose a discrete assembly for the cluster-free product, but crystallographic data are not available to confirm the structure. The templating ability of carboranes in coordination networks is reminiscent of the role that the fullerene $\mathrm{C}_{60}$ is known to play. However, templating cannot be guaranteed as is demonstrated in the reaction of 2 (Scheme 1) with $\mathrm{Ag}\left[\mathrm{Co}\left(\mathrm{C}_{2} \mathrm{~B}_{9} \mathrm{H}_{11}\right)_{2}\right]$ in $\mathrm{MeCN}$. Crystals isolated from this mixture have the composition $\left\{\left[\mathrm{Ag}(2)_{2}\right]\left[\mathrm{Co}\left(\mathrm{C}_{2} \mathrm{~B}_{9} \mathrm{H}_{11}\right)_{2}\right] \cdot 9 \mathrm{MeCN}\right\}_{n}$ and ligand 2 binds $\mathrm{Ag}^{+}$through only two of the three pyridyl domains generating a 1D-coordination polymer; chains are 
interwoven into 2D-sheets and the $\left[\mathrm{Co}\left(\mathrm{C}_{2} \mathrm{~B}_{9} \mathrm{H}_{11}\right)_{2}\right]^{-}$anions reside in channels between the sheets rather than being hosted in the bowl-shaped cavities of 2 . In contrast to the templating effects of the neutral carborane in $\left\{\left[\mathrm{Cd}(\mathrm{OAc})_{2}(\mathbf{1})\right] \cdot 2 \mathrm{H}_{2} \mathrm{O} \cdot 1,2-\mathrm{C}_{2} \mathrm{~B}_{10} \mathrm{H}_{12}\right\}_{n}$, the bulky $\left[\mathrm{Co}\left(\mathrm{C}_{2} \mathrm{~B}_{9} \mathrm{H}_{11}\right)_{2}\right]^{-}$anions in $\left\{\left[\mathrm{Ag}(2)_{2}\right]\left[\mathrm{Co}\left(\mathrm{C}_{2} \mathrm{~B}_{9} \mathrm{H}_{11}\right)_{2}\right] \cdot 9 \mathrm{MeCN}\right\}_{n}$ simply aid crystallization [9].

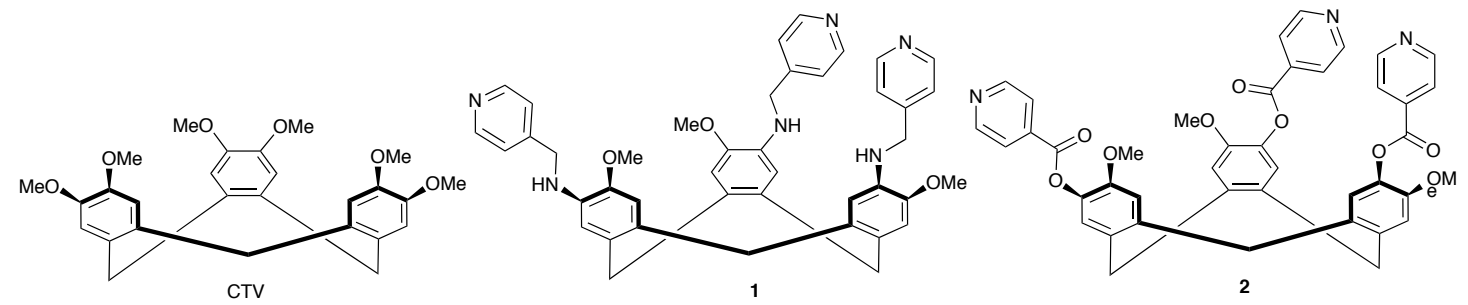

Scheme 1. Structures of cyclotriveratrylene (CTV), tris(4pyridylmethylamino)cyclotriguaiacylene (1) and tris(isonicotinoyl)cyclotriguaiacylene (2).

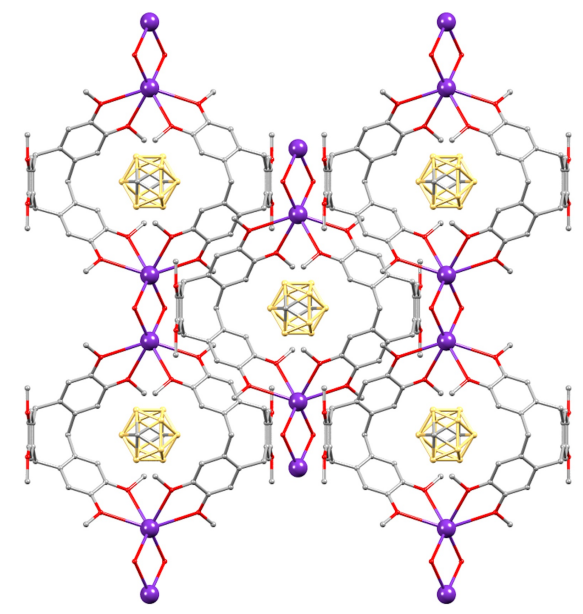

(a)

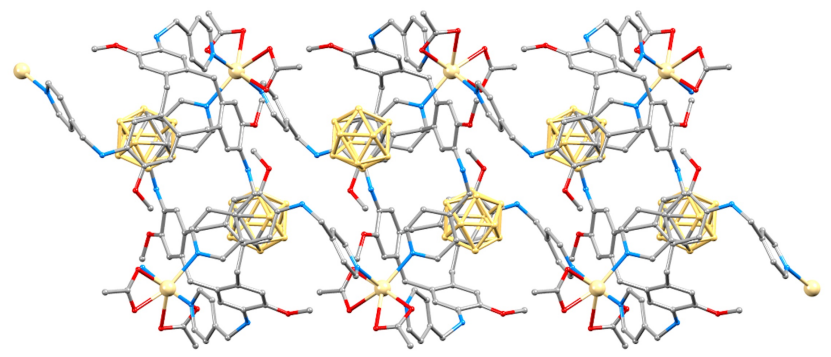

(b)

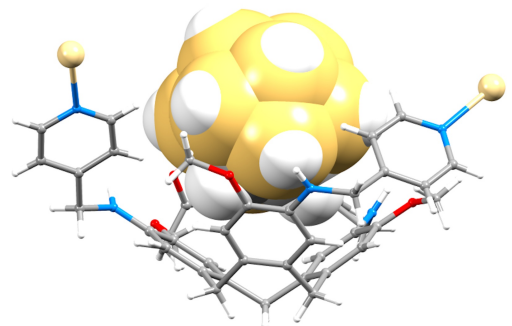

(c)

Fig. 1. Part of one sheet in (a) $\left\{\left[\mathrm{Rb}(\mathrm{CTV})_{2}(\mathrm{OH})\left(\mathrm{H}_{2} \mathrm{O}\right)_{2}\right] \cdot \mathrm{DMF} \cdot 1,2-\mathrm{C}_{2} \mathrm{~B}_{10} \mathrm{H}_{12}\right\}_{n}$ (CSD refcode XETTEV); $\mathrm{H}$ atoms and DMF molecules omitted, and (b) $\left\{\left[\mathrm{Cd}(\mathrm{OAc})_{2}(\mathbf{1})\right] \cdot 2 \mathrm{H}_{2} \mathrm{O} \cdot 1,2-\mathrm{C}_{2} \mathrm{~B}_{10} \mathrm{H}_{12}\right\}_{n}$ (refcode PUQKAO); $\mathrm{H}$ atoms and $\mathrm{H}_{2} \mathrm{O}$ molecules omitted. (c) Accommodation of a 1,2- $\mathrm{C}_{2} \mathrm{~B}_{10} \mathrm{H}_{12}$ molecule in the bowlshaped host in $\left\{\left[\mathrm{Cd}(\mathrm{OAc})_{2}(\mathbf{1})\right] \cdot 2 \mathrm{H}_{2} \mathrm{O} \cdot 1,2-\mathrm{C}_{2} \mathrm{~B}_{10} \mathrm{H}_{12}\right\}_{n}$. 


\section{Carborane anions: weakly coordinating or coordinatively innocent?}

The weakly coordinating nature of carborane anions allows them to act as putative linkers in coordination polymers. Many will argue that assemblies so formed are not true coordination polymers, the IUPAC definition of a coordination polymer being: 'a coordination compound with repeating coordination entities extending in 1, 2, or 3 dimensions' [10]. Nonetheless, the literature appears to have accepted the use of the term 'coordination polymer' where $\mathrm{B}-\mathrm{H} \cdots \mathrm{M}$ interactions are the primary interactions directing polymer or network assembly [11], despite the fact that the M...B separations (more accurately determined than M...H distances) are typically longer than observed in metal tetrahydridoborato complexes in which [ $\left.\mathrm{BH}_{4}\right]^{-}$ions are ligands [12]. In this section, B-H...Ag interactions are considered, and two popular anions are $\left[\mathrm{CB}_{11} \mathrm{H}_{12}\right]^{-}$and the metallocarborane $\left[\mathrm{Co}\left(\mathrm{C}_{2} \mathrm{~B}_{9} \mathrm{H}_{11}\right)_{2}\right]^{-}$(Scheme 2). Pertinent to the question of the strength of B-H.'Ag interactions is work from the Weller group. This gives NMR spectroscopic evidence for the persistence of $\mathrm{Ag}^{+\cdots . . .}$ cluster interactions in solution for $\left[\mathrm{CpMo}(\mathrm{CO})_{3} \mathrm{I} \cdot \mathrm{Ag}\left\{\mathrm{CB}_{11} \mathrm{H}_{12}\right\}\right]$, the solid state structure of which can be described in terms of a chain if B-H $\cdots A g$ contacts are included [13].
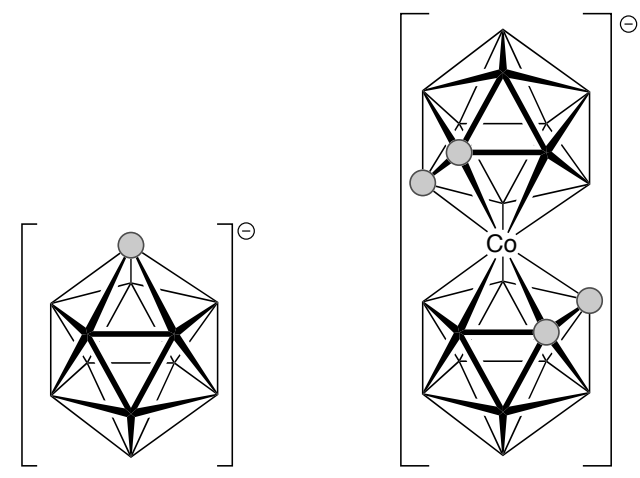

unmarked vertex $=\mathrm{BH}$

$\mathrm{O}=\mathrm{CH}$

Scheme 2. Schematic structures of $\left[\mathrm{CB}_{11} \mathrm{H}_{12}\right]^{-}$and $\left[\mathrm{Co}\left(\mathrm{C}_{2} \mathrm{~B}_{9} \mathrm{H}_{11}\right)_{2}\right]^{-}$.

The structural characterization of $\left\{\mathrm{Ag}\left[\mathrm{CB}_{11} \mathrm{H}_{12}\right] \cdot 2 \mathrm{C}_{6} \mathrm{H}_{6}\right\}_{n}$ [14] is significant for several reasons. In the authors' words, it provides the 'purest example' of intermolecular B-H-M bonding; it is also the first example of silver bound to an arene ring in an $\eta^{1}$-mode $(\mathrm{Ag}-\mathrm{C}=2.400(7) \AA)$, and the first example of a closocarborane with a single terminal B-H bond involved in a B-H-MM interaction. 1Dchains are assembled from alternating $\mathrm{Ag}^{+}$and $\left[\mathrm{CB}_{11} \mathrm{H}_{12}\right]^{-}$anions (Figure 2). It is 
worth comparing this structure with the polymer found in $\left\{\left[\mathrm{Et}_{3} \mathrm{BzN}\right] \mathrm{Ag}\left[\mathrm{B}_{12} \mathrm{H}_{12}\right]\right\}_{n}$ [15]; formally, [ $\left.\mathrm{CB}_{11} \mathrm{H}_{12}\right]^{-}$cages are replaced by $\left[\mathrm{B}_{12} \mathrm{H}_{12}\right]^{2-}$ clusters, although the change in overall charge requires the accommodation of cations (in this case benzyltriethylammonium). In the solid state, $\left\{\left[\mathrm{Et}_{3} \mathrm{BzN}\right] \mathrm{Ag}\left[\mathrm{B}_{12} \mathrm{H}_{12}\right]\right\}_{n}$ consists of double chains in which each cage is bound to three $\mathrm{Ag}^{+}$ions (Figure 3).

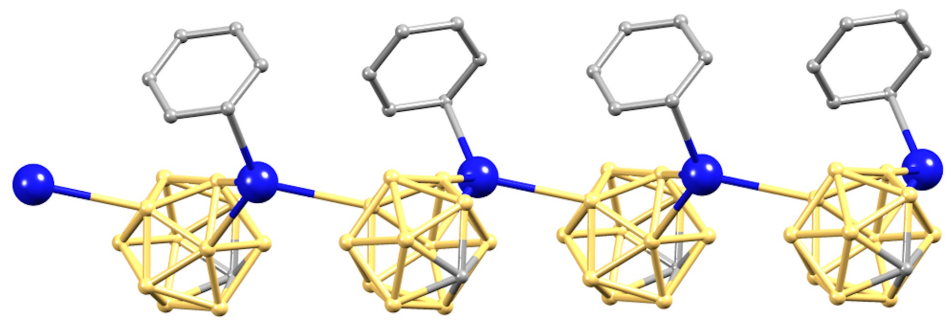

Figure 2. Part of a 1D-chain in $\left\{\mathrm{Ag}\left[\mathrm{CB}_{11} \mathrm{H}_{12}\right] \cdot 2 \mathrm{C}_{6} \mathrm{H}_{6}\right\}_{n}$ (refcode DEGWUH); $\mathrm{H}$ atoms and non-bonded $\mathrm{C}_{6} \mathrm{H}_{6}$ omitted.

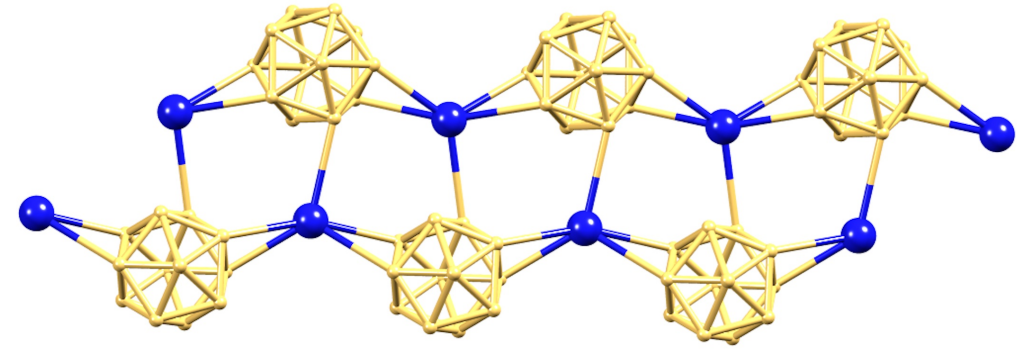

Figure 3. Part of a 1D-chain in $\left\{\left[\mathrm{Et}_{3} \mathrm{BzN}\right] \mathrm{Ag}\left[\mathrm{B}_{12} \mathrm{H}_{12}\right]\right\}_{n}$ (refcode GAPHUB); H atoms omitted $(\mathrm{Bz}=$ benzyl $)$.

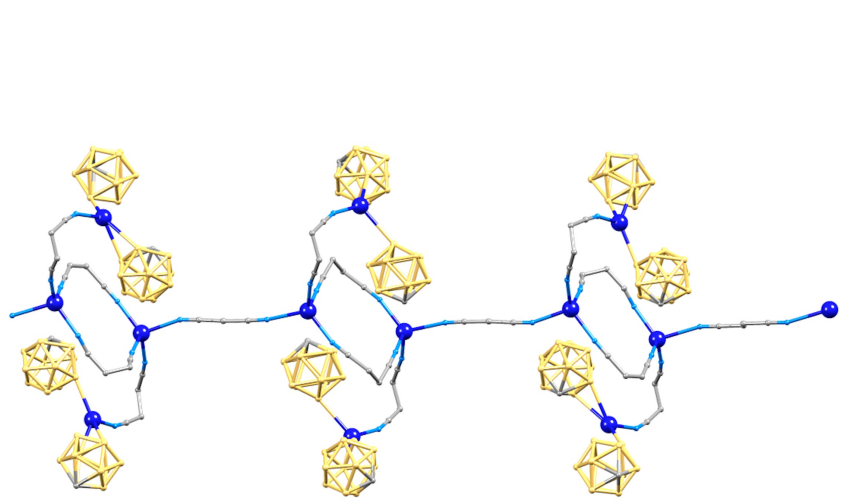

(a)

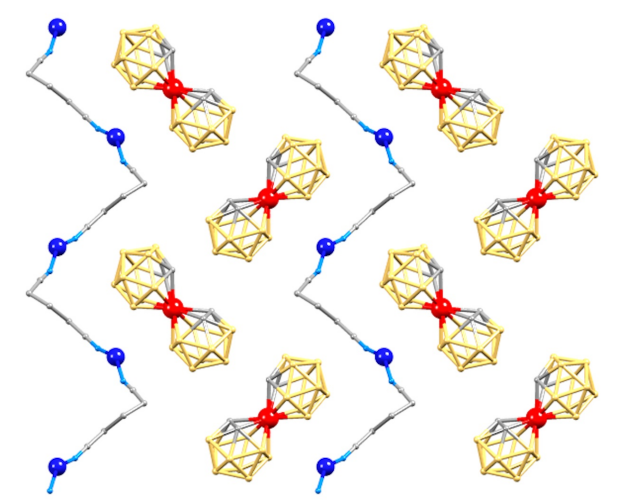

(b)

Figure 4. (a) Part of a 1D-chain in $\left\{\left[\mathrm{Ag}_{4}\left(\mathrm{NC}\left(\mathrm{CH}_{2}\right)_{2} \mathrm{CN}\right)_{5}\right]\left[\mathrm{CB}_{11} \mathrm{H}_{12}\right]_{4}\right\}_{n}$ and (b) arrangement of cationic $1 \mathrm{D}$-coordination polymer chains and $\left[\mathrm{Co}\left(\mathrm{C}_{2} \mathrm{~B}_{9} \mathrm{H}_{11}\right)_{2}\right]^{-}$ ions in $\left\{\left[\mathrm{Ag}\left(\mathrm{NC}\left(\mathrm{CH}_{2}\right)_{3} \mathrm{CN}\right)\right]\left[\mathrm{Co}\left(\mathrm{C}_{2} \mathrm{~B}_{9} \mathrm{H}_{11}\right)_{2}\right]\right\}_{n}$. Refcodes IZOTAS and IZOTIA; $\mathrm{H}$ atoms are omitted. 
Tuning of the $\mathrm{Ag}\left[\mathrm{CB}_{11} \mathrm{H}_{12}\right]$ motif while retaining $\mathrm{B}-\mathrm{H} \cdots \mathrm{Ag}$ interactions has been made by adding nitrile-, amino- or pyridine-based ligands. Not all are true coordination polymers within the IUPAC guidelines, e.g. in $\left[\mathrm{Ag}(\mathrm{MeCN})_{2}\right]\left[\mathrm{CB}_{11} \mathrm{H}_{12}\right]$, the assembly consists of arc-shaped $\left[\mathrm{Ag}(\mathrm{MeCN})_{2}\right]^{+}$ cations, each engaging in close $\mathrm{Ag} \cdots \mathrm{H}-\mathrm{B}$ contacts with three $\left[\mathrm{CB}_{11} \mathrm{H}_{12}\right]^{-}$ions [16]. Crystal growth from a mixture of $\mathrm{Ag}\left[\mathrm{CB}_{11} \mathrm{H}_{12}\right]$ and succinonitrile in ethanol gives $\left\{\left[\mathrm{Ag}_{4}\left(\mathrm{NC}\left(\mathrm{CH}_{2}\right)_{2} \mathrm{CN}\right)_{5}\right]\left[\mathrm{CB}_{11} \mathrm{H}_{12}\right]_{4}\right\}_{n}$ in which bridging dinitrile ligands link $\mathrm{Ag}^{+}$ cations into a 1D-chain; branches from the coordination polymer backbone lead to terminal $\mathrm{Ag}^{+}$ions which form $\mathrm{Ag} \cdot \mathrm{H}-\mathrm{B}$ contacts to $\left[\mathrm{CB}_{11} \mathrm{H}_{12}\right]^{-}$anions (Figure 4a) [16]. A $1: 1$ mixture of $\mathrm{Ag}\left[\mathrm{CB}_{11} \mathrm{H}_{12}\right]$ and glutaronitrile leads to a cationic 1Dcoordination polymer; the chains pack with $\left[\mathrm{Co}\left(\mathrm{C}_{2} \mathrm{~B}_{9} \mathrm{H}_{11}\right)_{2}\right]^{-}$anions accommodated in between (Figure 4b) and with short B-H $\cdots$ Ag interactions [16]. Related cationic chains interspersed with $\left[\mathrm{Co}\left(\mathrm{C}_{2} \mathrm{~B}_{9} \mathrm{H}_{11}\right)_{2}\right]^{-}$counterions are observed in $\left\{\left[\mathrm{Ag}\left(\mathrm{NC}\left(\mathrm{CH}_{2}\right)_{4} \mathrm{CN}\right)\right]\left[\mathrm{Co}\left(\mathrm{C}_{2} \mathrm{~B}_{9} \mathrm{H}_{11}\right)_{2}\right]\right\}_{n}$, $\left\{\left[\mathrm{Ag}\left(\mathrm{NC}\left(\mathrm{CH}_{2}\right)_{3} \mathrm{CN}\right)_{2}\right]\left[\mathrm{Co}\left(\mathrm{C}_{2} \mathrm{~B}_{9} \mathrm{H}_{11}\right)_{2}\right]\right\}_{n}[16]$, $\left\{\left[\mathrm{Ag}\left(\mathrm{NC}\left(\mathrm{CH}_{2}\right)_{5} \mathrm{CN}\right)\right]\left[\mathrm{Co}\left(\mathrm{C}_{2} \mathrm{~B}_{9} \mathrm{H}_{11}\right)_{2}\right] \cdot \mathrm{Ag}\left[\mathrm{Co}\left(\mathrm{C}_{2} \mathrm{~B}_{9} \mathrm{H}_{11}\right)_{2}\right]\right\}_{n}$ and $\left\{\left[\mathrm{Ag}_{3}\left(\mathrm{NC}\left(\mathrm{CH}_{2}\right)_{6} \mathrm{CN}\right)_{2}\right]\left[\mathrm{Co}\left(\mathrm{C}_{2} \mathrm{~B}_{9} \mathrm{H}_{11}\right)_{2}\right]_{3}\right\}_{n}[17]$.

The change from $\left[\mathrm{CB}_{11} \mathrm{H}_{12}\right]^{-}$to the more bulky $\left[\mathrm{Co}\left(\mathrm{C}_{2} \mathrm{~B}_{9} \mathrm{H}_{11}\right)_{2}\right]^{-}$has a significant effect on the 1D-coordination polymer formed between $\mathrm{Ag}$ [carborane anion] and pyrazine (pyz); crystallizations were carried out from MeCN solutions [18]. Pyrazine acts as a bridging ligand, linking $\mathrm{Ag}^{+}$ions into 1D-polymer chains in both $\left\{[\mathrm{Ag}(\mathrm{pyz})]\left[\mathrm{CB}_{11} \mathrm{H}_{12}\right]\right\}_{n}$ and $\left\{\left[\mathrm{Ag}(\mathrm{pyz})(\mathrm{MeCN})_{2}\right]\left[\mathrm{Co}\left(\mathrm{C}_{2} \mathrm{~B}_{9} \mathrm{H}_{11}\right)_{2}\right]\right\}_{n}$; in the former, $\mathrm{Ag}^{+}$is 2-coordinate (Figure $5 \mathrm{a}$ ) whereas in the latter, coordinated $\mathrm{MeCN}$ molecules increase the coordination number to four (Figure 5b). Hardie and coworkers [18] describe the lattice in $\left\{[\mathrm{Ag}(\mathrm{pyz})]\left[\mathrm{CB}_{11} \mathrm{H}_{12}\right]\right\}_{n}$ as comprising a 3Dcoordination network. However, this description necessitates the inclusion of B$\mathrm{H} \cdot \cdots \mathrm{Ag}$ contacts (not shown in Figure 5a) which link the true 1D-coordination polymer chains into a higher-dimensionality framework. Replacing $\left[\mathrm{CB}_{11} \mathrm{H}_{12}\right]^{-}$by $\left[\mathrm{Co}\left(\mathrm{C}_{2} \mathrm{~B}_{9} \mathrm{H}_{11}\right)_{2}\right]^{-}$ions switches off the $\mathrm{B}-\mathrm{H} \cdots \mathrm{Ag}$ interactions, leading to the structure shown in Figure 5c. Coordination polymer chains in $\left\{\left[\mathrm{Ag}(\mathrm{pyz})(\mathrm{MeCN})_{2}\right]\left[\mathrm{Co}\left(\mathrm{C}_{2} \mathrm{~B}_{9} \mathrm{H}_{11}\right)_{2}\right]\right\}_{n}$ are aligned in pairs, interacting through

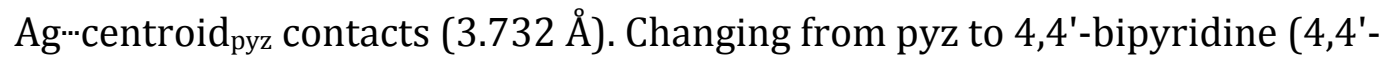
bpy) in the reaction with $\mathrm{Ag}\left[\mathrm{Co}\left(\mathrm{C}_{2} \mathrm{~B}_{9} \mathrm{H}_{11}\right)_{2}\right]$ in $\mathrm{MeCN}$ leads to the 1D-coordination 
polymer $\left\{[\mathrm{Ag}(4,4 \text { '-bpy })(\mathrm{MeCN})]\left[\mathrm{Co}\left(\mathrm{C}_{2} \mathrm{~B}_{9} \mathrm{H}_{11}\right)_{2}\right]\right\}_{n}$ in which 4,4'-bpy links pairs of $\mathrm{Ag}^{+}$ions, each of which additionally binds one MeCN molecule. As in $\left\{\left[\mathrm{Ag}(\mathrm{pyz})(\mathrm{MeCN})_{2}\right]\left[\mathrm{Co}\left(\mathrm{C}_{2} \mathrm{~B}_{9} \mathrm{H}_{11}\right)_{2}\right]\right\}_{n}, \mathrm{Ag}$ ‥centroid ${ }_{\text {pyz }}$ contacts (3.558 $\mathrm{A}$ ) between chains in $\left\{\left[\mathrm{Ag}\left(4,4^{\prime}-\mathrm{bpy}\right)(\mathrm{MeCN})\right]\left[\mathrm{Co}\left(\mathrm{C}_{2} \mathrm{~B}_{9} \mathrm{H}_{11}\right)_{2}\right]\right\}_{n}$ play a role; they are supplemented by face-to-face $\pi$-interactions between 4,4'-bpy domains (Figure 6). The $\left[\mathrm{Co}\left(\mathrm{C}_{2} \mathrm{~B}_{9} \mathrm{H}_{11}\right)_{2}\right]^{-}$ions reside in channels running through the lattice. $\mathrm{A}$ second polymorph of $\left\{\left[\mathrm{Ag}\left(4,4^{\prime}-\text { bpy }\right)(\mathrm{MeCN})\right]\left[\mathrm{Co}\left(\mathrm{C}_{2} \mathrm{~B}_{9} \mathrm{H}_{11}\right)_{2}\right]\right\}_{n}$ possesses very similar structural characteristics. Similarly, in $\left\{\left[\mathrm{Ag}_{2}(\mathrm{bppz})_{2}\left[\mathrm{Co}\left(\mathrm{C}_{2} \mathrm{~B}_{9} \mathrm{H}_{11}\right)_{2}\right]_{2}\right\}_{n}\right.$ (bppz $=2,3$-bis(2-pyridyl)pyrazine), 1D-coordination polymer chains comprising $\mathrm{Ag}^{+}$ions linked by bridging bppz ligands are separated by $\left[\mathrm{Co}_{(}\left(\mathrm{C}_{2} \mathrm{~B}_{9} \mathrm{H}_{11}\right)_{2}\right]^{-}$ions, and the latter are not involved chain assembly [18]. A comparable assembly is observed in $\left\{[\mathrm{Ag}(\text { dabco })]\left[\mathrm{Co}\left(\mathrm{C}_{2} \mathrm{~B}_{9} \mathrm{H}_{11}\right)_{2}\right]\right\}_{n}$ with linear $\left\{[\mathrm{Ag}(\text { dabco })]^{+}\right\}_{n}$ chains defining the coordination polymer domain (Figure 7a,b); B-H-'Ag separations are in the range 2.4456(2)-2.8958(1) $\AA$ and are therefore very weak [19]. However, exchange of $\left[\mathrm{Co}\left(\mathrm{C}_{2} \mathrm{~B}_{9} \mathrm{H}_{11}\right)_{2}\right]^{-}$for $\left[1-\mathrm{PhCB}_{9} \mathrm{H}_{9}\right]^{-}$results in the $\left\{[\mathrm{Ag}(\text { dabco })]^{+}\right\}_{n}$ chains propagating in a zigzag manner (Figure $7 \mathrm{c}$ ) with each $\left[1-\mathrm{PhCB}_{9} \mathrm{H}_{9}\right]^{-}$cage forming a rather short $\mathrm{B}-\mathrm{H} \cdots \cdot \mathrm{Ag}$ contact $(\mathrm{Ag} \cdots \cdot \mathrm{H}=1.862(1) \AA)$ which is more typical of a distance observed in tetrahydridoborate complexes of d-block metals [12]. In this case, the authors describe the B-H $\cdots \mathrm{Ag}$ contact as an agostic interaction [19]. Each carborane cage in $\left\{\left[\mathrm{Ag}(\mathrm{dabco})\left(\mathrm{PhCB}_{9} \mathrm{H}_{9}\right)\right]\right\}_{n}$ also engages in a second, weaker B-H..'Ag contact at a separation of 2.353(1) A. A related assembly is observed in the solid-state structure of $\left\{\left[\mathrm{Ag}(\mathrm{bppz})\left(\mathrm{PhCB}_{9} \mathrm{H}_{9}\right)\right] \cdot 0.5 \mathrm{MeCN}\right\}_{n}$ (Figure 9), although the closest B-H'*Ag separation of $2.29 \AA$ [20] is significantly longer than in $\left\{\left[\mathrm{Ag}(\text { dabco })\left(\mathrm{PhCB}_{9} \mathrm{H}_{9}\right)\right]\right\}_{n}$. This assembly contrasts with that in $\left\{\left[\mathrm{Ag}\left(4,4^{\prime}-\text {-bpy }\right)\right]\left[\mathrm{PhCB}_{9} \mathrm{H}_{9}\right] \cdot \mathrm{MeCN}\right\}_{n}$ where cationic 1D-polymer chains and carborane counterions show no interaction [20]. 

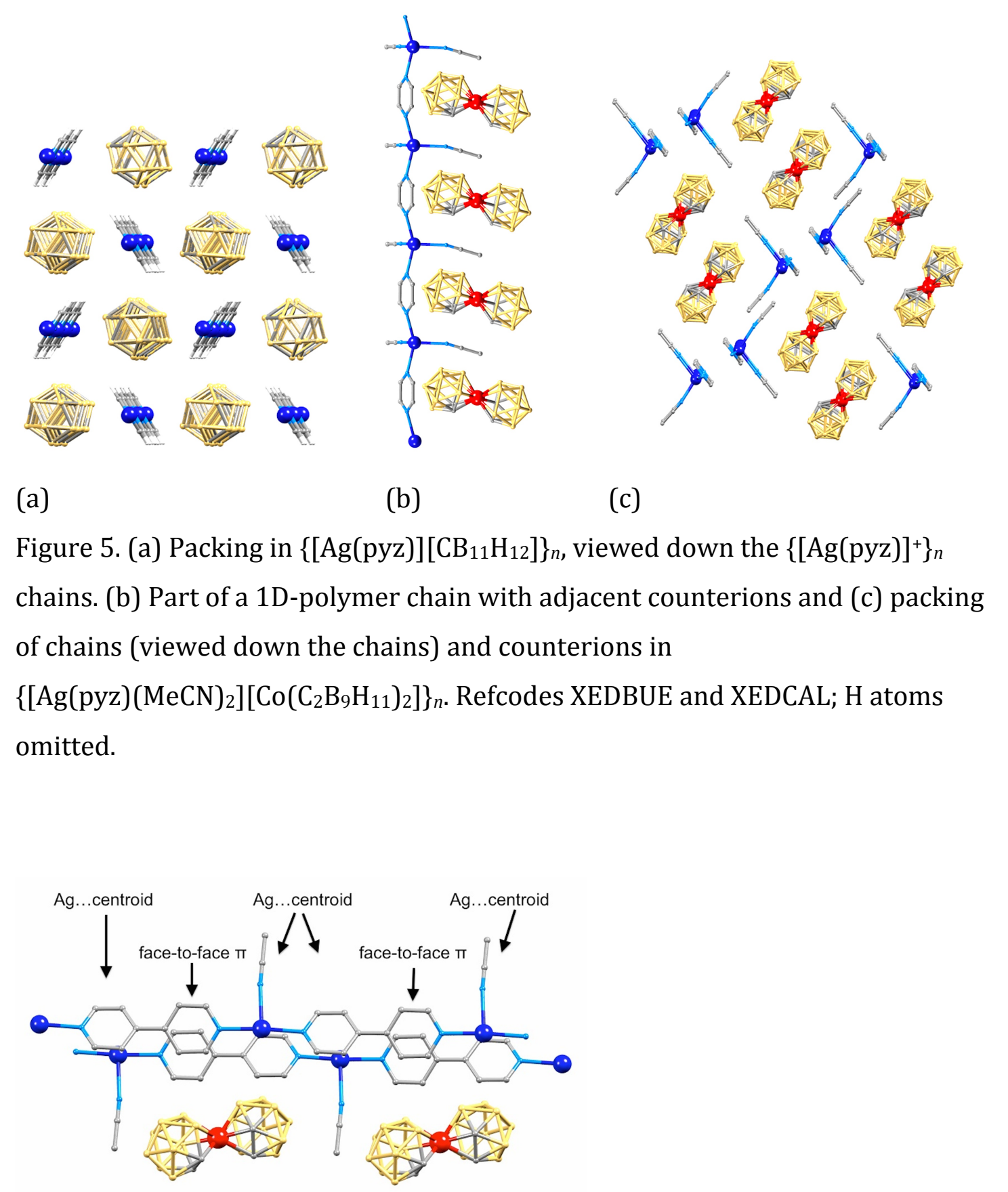

Figure 6. Interactions between adjacent coordination polymer chains in $\left\{\left[\mathrm{Ag}\left(4,4^{\prime}-\text { bpy }\right)(\mathrm{MeCN})\right]\left[\mathrm{Co}\left(\mathrm{C}_{2} \mathrm{~B}_{9} \mathrm{H}_{11}\right)_{2}\right]\right\}_{n}$ and location of counterions with respect to the chains. Refcode XEDCEP; H atoms omitted. 


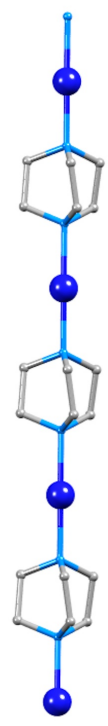

(a)

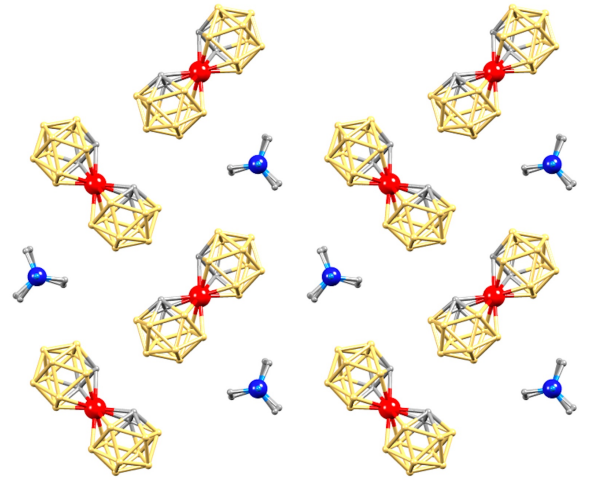

(b)

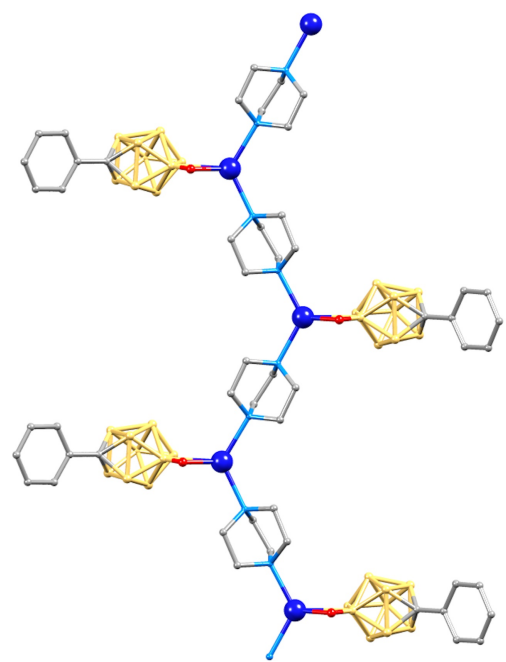

(c)

Figure 7. (a), (b) The structure of $\left\{[\mathrm{Ag}(\mathrm{dabco})]\left[\mathrm{Co}\left(\mathrm{C}_{2} \mathrm{~B}_{9} \mathrm{H}_{11}\right)_{2}\right]\right\}_{n}$ : (a) part of one cationic 1D-chain, and (b) packing of chains and $\left[\mathrm{Co}\left(\mathrm{C}_{2} \mathrm{~B}_{9} \mathrm{H}_{11}\right)_{2}\right]^{-}$ions, viewed along the axes of the chains. (c) Part of one zigzag chain in $\left\{\left[\mathrm{Ag}(\text { dabco })\left(\mathrm{PhCB}_{9} \mathrm{H}_{9}\right)\right]\right\}_{n}$. Refcodes HIQLUK and HIQLOK; $\mathrm{H}$ atoms omitted except for $\mathrm{B}-\mathrm{H} \cdots \mathrm{Ag} \mathrm{H}$ atoms (shown in red) in part (c).

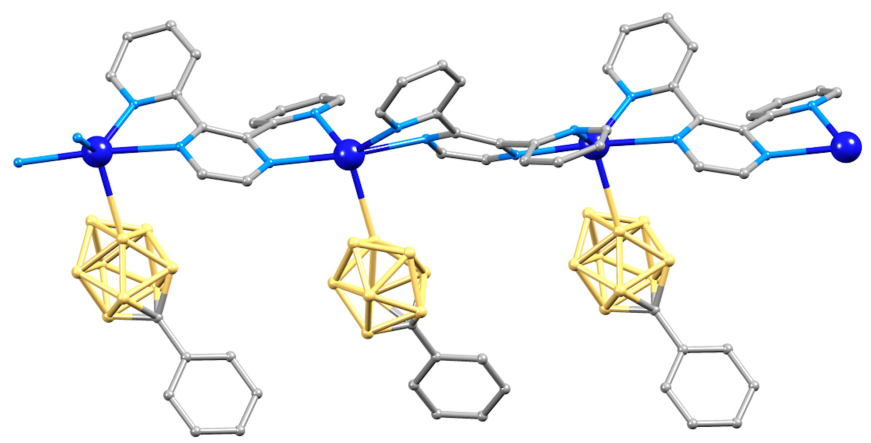

Figure 8. Part of the 1D-polymer chain in $\left\{\left[\mathrm{Ag}(\mathrm{bppz})\left(\mathrm{PhCB}_{9} \mathrm{H}_{9}\right)\right] \cdot 0.5 \mathrm{MeCN}\right\}$. Refcode KIDQUE; $\mathrm{H}$ atoms and MeCN molecules omitted.

\section{Halo-substituted carboranes as bridging domains}

Replacing B-H by B-X (X = C, Br or I) removes much of the ambiguity surrounding the role of a carborane cluster anion in a ligand. A direct comparison between the structures of $\left\{\left[\mathrm{Ag}(\mathrm{dabco})\left(\mathrm{PhCB}_{9} \mathrm{H}_{9}\right)\right]\right\}_{n}$ and $\left\{\left[\mathrm{Ag}(\mathrm{dabco})\left(\mathrm{PhCB}_{9} \mathrm{H}_{8} \mathrm{I}\right)\right]\right\}_{n}$ is instructive. The iodo-substituent is introduced in the 6-position of the cage, mimicking the position of the $\mathrm{H}$ that participates in the 
B-H*'Ag interaction in $\left\{\left[\mathrm{Ag}(\text { dabco })\left(\mathrm{PhCB}_{9} \mathrm{H}_{9}\right)\right]\right\}_{n}$ (Figure $\left.7 \mathrm{c}\right)$. The same zigzag polymer chain is observed in both compounds. The $\mathrm{N}-\mathrm{Ag}-\mathrm{N}$ angle increases from $123.22(1)$ to $142.57(8)^{\circ}$ on going from $\left\{\left[\mathrm{Ag}(\mathrm{dabco})\left(\mathrm{PhCB}_{9} \mathrm{H}_{9}\right)\right]\right\}_{n}$ to $\left\{\left[\mathrm{Ag}(\mathrm{dabco})\left(\mathrm{PhCB}_{9} \mathrm{H}_{8} \mathrm{I}\right)\right]\right\}_{n}$, and the orientations of the clusters with respect to the chains in the two coordination polymers are compared in Figures 9a and 9b. The carborane cage in the iodo-complex is folded back towards the chain, and this is associated with a weak B-H*'Ag contact (2.6097(3) $\AA$ ) analogous to the second B-H $\cdots A$ Ag contact (2.353(1) $\AA$ ) in $\left\{\left[\mathrm{Ag}(\text { dabco })\left(\mathrm{PhCB}_{9} \mathrm{H}_{9}\right)\right]\right\}_{n}$. The much longer Ag-I bond distance (2.9155(4) $\AA)$ in $\left\{\left[\mathrm{Ag}(\text { dabco })\left(\mathrm{PhCB}_{9} \mathrm{H}_{8} \mathrm{I}\right)\right]\right\}_{n}$ compared to the Ag..'H separation of $1.862(1) \AA\left\{\left[\mathrm{Ag}(\text { dabco })\left(\mathrm{PhCB}_{9} \mathrm{H}_{9}\right)\right]\right\}_{n}$ necessitates the bending in of the cage. A conformation closer to that in $\left\{\left[\mathrm{Ag}(\mathrm{dabco})\left(\mathrm{PhCB}_{9} \mathrm{H}_{9}\right)\right]\right\}_{n}$ is regained on introducing the $\left[1-\mathrm{PhC}-7,8,9,10,11,12-\mathrm{B}_{11} \mathrm{H}_{5} \mathrm{I}_{6}\right]^{-}$anion (compare Figures 9a and 9c with Figure 9b) which can act as a bidentate ligand through two B-I-Ag interactions [19].

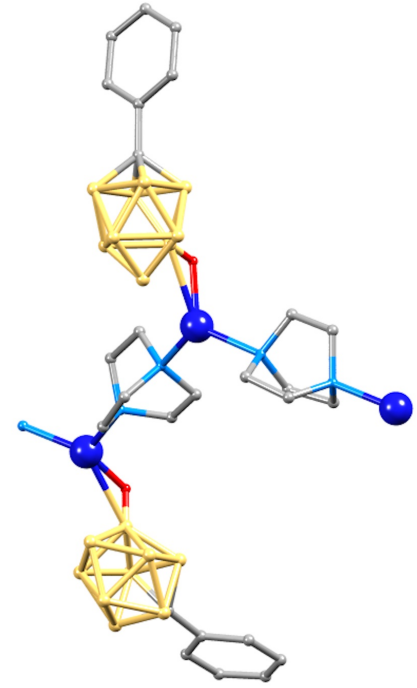

(a)

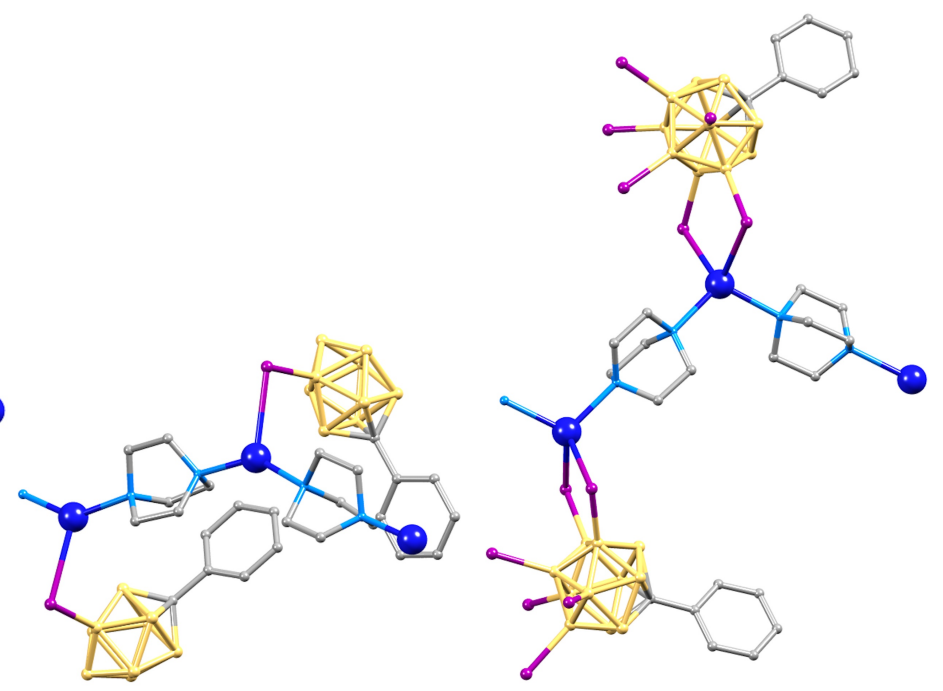

(b) (c)

Figure 9. Analogous parts of 1D-chains in (a) $\left\{\left[\mathrm{Ag}(\mathrm{dabco})\left(\mathrm{PhCB}_{9} \mathrm{H}_{9}\right)\right]\right\}_{n}$, (b) $\left\{\left[\mathrm{Ag}(\text { dabco })\left(\mathrm{PhCB}_{9} \mathrm{H}_{8} \mathrm{I}\right)\right]\right\}_{n}$, and (c) $\left\{\left[\mathrm{Ag}(\text { dabco })\left(\mathrm{PhCB}_{11} \mathrm{H}_{5} \mathrm{I}_{6}\right)\right]\right\}_{n}$. Refcodes HIQLOK, HIQLIE and HIQLEA; H atoms omitted except for B-H.'Ag H atoms (shown in red) in part (a). 
In Section 3, the coordination polymer $\left\{\left[\mathrm{Ag}\left(4,4^{\prime}-\mathrm{bpy}\right)\right]\left[\mathrm{PhCB}_{9} \mathrm{H}_{9}\right] \cdot \mathrm{MeCN}\right\}_{n}$ was considered, and it was concluded that the carborane anions were essentially innocent in terms of polymer assembly. On the other hand, in $\left\{\left[\mathrm{Ag}(\mathrm{bppz})\left(\mathrm{PhCB}_{9} \mathrm{H}_{9}\right)\right] \cdot 0.5 \mathrm{MeCN}\right\}_{n}$ and $\left\{\left[\mathrm{Ag}\left(\text { dabco }\left(\mathrm{PhCB}_{9} \mathrm{H}_{9}\right)\right]\right\}_{n}\right.$, there is evidence for B-H'-Ag interactions (Figures 8c and 9). Hardie and coworkers [20] have extended these investigations to the halogenated clusters $\left[\mathrm{PhCB}_{9} \mathrm{H}_{4} \mathrm{I}_{5}\right]^{-}$, $\left[\mathrm{PhCB}_{11} \mathrm{H}_{5} \mathrm{I}_{6}\right]^{-}$and $\left[\mathrm{PhCB}_{9} \mathrm{H}_{8} \mathrm{Br}\right]^{-}$. Both $\left\{\left[\mathrm{Ag}\left(4,4^{\prime}-\mathrm{bpy}\right)\left(\mathrm{PhCB}_{11} \mathrm{H}_{5} \mathrm{I}_{6}\right)\right] \cdot \mathrm{MeCN}\right\}_{n}$ (Figure 10) and $\left\{\left[\mathrm{Ag}(4,4 '-\mathrm{bpy})\left(\mathrm{PhCB}_{9} \mathrm{H}_{4} \mathrm{I}_{5}\right)\right] \cdot \mathrm{MeCN}\right\}_{n}$ possess zigzag 1D-chains which are structurally related to that in $\left\{\left[\mathrm{Ag}(\mathrm{dabco})\left(\mathrm{PhCB}_{11} \mathrm{H}_{5} \mathrm{I}_{6}\right)\right]\right\}_{n}$ (Figure 9c). Crystal growth from a mixture of $\mathrm{Ag}\left[\mathrm{PhCB}_{9} \mathrm{H}_{8} \mathrm{Br}\right]$ with bppz in $\mathrm{MeCN}$ results in the formation of $\left[\mathrm{Ag}(\mathrm{bppz})\left(\mathrm{PhCB}_{9} \mathrm{H}_{8} \mathrm{Br}\right)\right]_{2}$. In $\left\{\left[\mathrm{Ag}(\mathrm{bppz})\left(\mathrm{PhCB}_{9} \mathrm{H}_{9}\right)\right] \cdot 0.5 \mathrm{MeCN}\right\}_{n}$, the bppz ligand acts in a bis(bidentate) mode and is a linker in a polymeric chain. In contrast, one $\mathrm{N}$-donor of bppz in $\left[\mathrm{Ag}(\mathrm{bppz})\left(\mathrm{PhCB}_{9} \mathrm{H}_{8} \mathrm{Br}\right)\right]_{2}$ remains noncoordinated; the ligand backbone is more twisted than in $\left\{\left[\mathrm{Ag}(\mathrm{bppz})\left(\mathrm{PhCB}_{9} \mathrm{H}_{9}\right)\right] \cdot 0.5 \mathrm{MeCN}\right\}_{n}$, and the dimer shown in Figure 11 assembles.

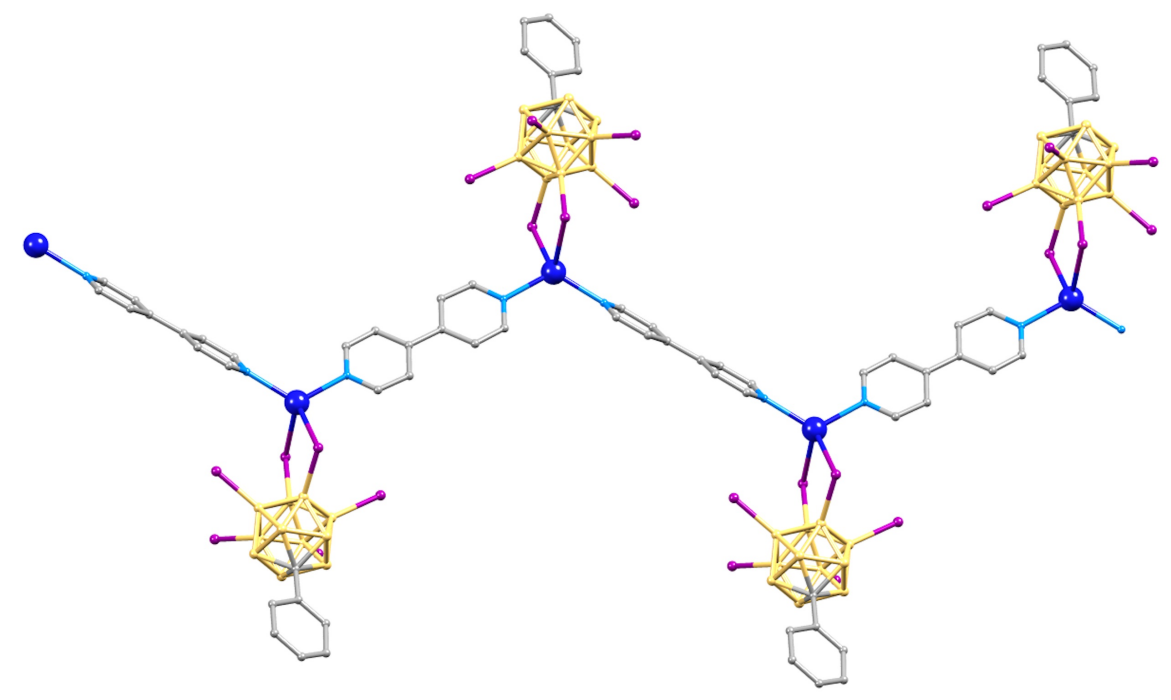

Figure 10. Part of a 1D-coordination polymer chain in $\{[\operatorname{Ag}(4,4 '-$ bpy) $\left.\left(\mathrm{PhCB}_{11} \mathrm{H}_{5} \mathrm{I}_{6}\right)\right] \cdot \mathrm{MeCN}_{n} ; \mathrm{H}$ atoms omitted (refcode KIDQAQ). 


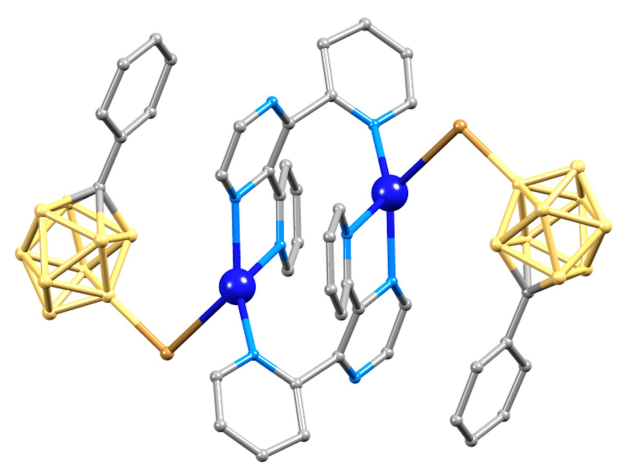

Figure 11. The structure of the dimer $\left[\mathrm{Ag}(\mathrm{bppz})\left(\mathrm{PhCB}{ }_{9} \mathrm{H}_{8} \mathrm{Br}\right)\right]_{2}$; the twist angle between the mono-pyridine and pyrazine rings is $54.3^{\circ}$. Refcode KIDQOE; H atoms omitted.

Figure 2 showed the structure of $\left\{\mathrm{Ag}\left[\mathrm{CB}_{11} \mathrm{H}_{12}\right] \cdot 2 \mathrm{C}_{6} \mathrm{H}_{6}\right\}_{n}$; its description as a 1D-coordination polymer depends upon ones interpretation of the cation "*anion interactions. Crystallization of the halo-derivatives $\mathrm{Ag}\left[\mathrm{CB}_{11} \mathrm{H}_{6} \mathrm{X}_{6}\right]$ from 1,4- $\mathrm{Me}_{2} \mathrm{C}_{6} \mathrm{H}_{4}$ for $\mathrm{X}=\mathrm{Cl}$, from $\mathrm{MeC}_{6} \mathrm{H}_{5} /{ }^{2} \mathrm{Pr}_{2} \mathrm{SiHCl}$ for $\mathrm{X}=\mathrm{Br}$, and from $\mathrm{C}_{6} \mathrm{H}_{6} / \mathrm{MeCN}$ for $\mathrm{X}=\mathrm{I}$ results in the isolation of $\left\{\mathrm{Ag}\left[\mathrm{CB}_{11} \mathrm{H}_{6} \mathrm{Cl}_{6}\right] \cdot 1,4-\mathrm{Me}_{2} \mathrm{C}_{6} \mathrm{H}_{4}\right\}_{n}$, $\left\{\mathrm{Ag}\left[\mathrm{CB}_{11} \mathrm{H}_{6} \mathrm{Br}_{6}\right]\right\}_{n}$ and $\left\{\mathrm{Ag}\left[\mathrm{CB}_{11} \mathrm{H}_{6} \mathrm{I}_{6}\right] \cdot 0.5 \mathrm{C}_{6} \mathrm{H}_{6}\right\}_{n}$ [21]. Each consists of 1Dcoordination polymer chains comprising alternating silver and carborane units. In $\left\{\mathrm{Ag}\left[\mathrm{CB}_{11} \mathrm{H}_{6} \mathrm{I}_{6}\right] \cdot 0.5 \mathrm{C}_{6} \mathrm{H}_{6}\right\}_{n}$, the benzene solvent molecules occupy cavities in the lattice, while in $\left\{\mathrm{Ag}\left[\mathrm{CB}_{11} \mathrm{H}_{6} \mathrm{Cl}_{6}\right] \cdot 1,4-\mathrm{Me}_{2} \mathrm{C}_{6} \mathrm{H}_{4}\right\}_{n}$, the arene ring binds to the $\mathrm{Ag}^{+}$ion in an $\eta^{2}$-mode; contrast the $\eta^{1}$-mode of one solvent molecule in $\left\{\mathrm{Ag}\left[\mathrm{CB}_{11} \mathrm{H}_{12}\right] \cdot 2 \mathrm{C}_{6} \mathrm{H}_{6}\right\}_{n}$. The structures of the three complexes are compared in Figure 12. The iodo- and bromo-derivatives are analogous, save for the modification of a $\mu$-I into a $\mu_{3}-\mathrm{Br}$ ligand (compare Figures $12 \mathrm{a}$ and $12 \mathrm{~b}$ ). In the chloro-derivative, the presence of two non-coordinating) $\mathrm{Cl}$ atoms per cluster (compared to one Br or I in the other two polymers) is consistent with the additional coordination of the $\eta^{2}-1,4-\mathrm{Me}_{2} \mathrm{C}_{6} \mathrm{H}_{4}$ to the $\mathrm{Ag}^{+}$ion. Such $\eta^{1-}$ and $\eta^{2-}$ interactions are also observed in $\left\{\mathrm{Ag}\left[1-\mathrm{Me}-12-\mathrm{Ph}_{3} \mathrm{Si}_{-} \mathrm{CB}_{11} \mathrm{~F}_{10}\right] \cdot 0.5 \mathrm{C}_{6} \mathrm{H}_{6}\right\}_{n}$ (Figure 13), an organometallic polymer included here merely for comparison [22], and in $\left\{\mathrm{Ag}\left[\mathrm{CHPh}_{3}\right] \cdot 1-\mathrm{Me}-\mathrm{CB}_{11} \mathrm{~F}_{11}\right\}_{n}$ which consists of $2 \mathrm{D}$-sheets (again with $\mathrm{Ag}-\mathrm{C}$ bonds) [23]. The $\left[\mathrm{CB}_{11} \mathrm{H}_{6} \mathrm{Br}_{6}\right]^{-}$cluster (Figure $12 \mathrm{~b}$ ) also features as a bridging ligand in $\left\{\mathrm{Et}_{3} \mathrm{Ge}\left(\mathrm{CB}_{11} \mathrm{H}_{6} \mathrm{Br}_{6}\right)\right\}_{n},\left\{\mathrm{Et}_{3} \mathrm{Sn}\left(\mathrm{CB}_{11} \mathrm{H}_{6} \mathrm{Br}_{6}\right)\right\}_{n}$ and $\left\{\mathrm{Et}_{3} \mathrm{~Pb}\left(\mathrm{CB}_{11} \mathrm{H}_{6} \mathrm{Br}_{6}\right)\right\}_{n}$ [24]. 


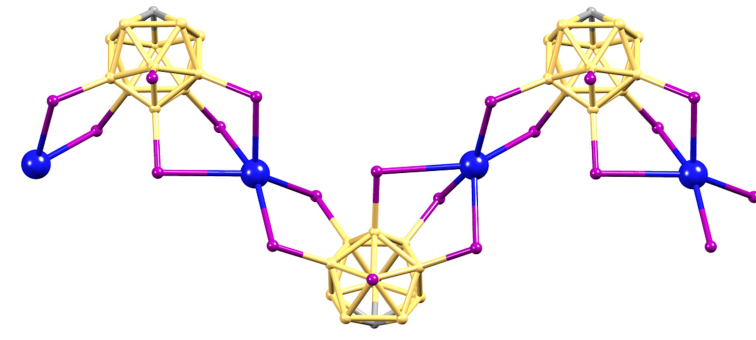

(a)

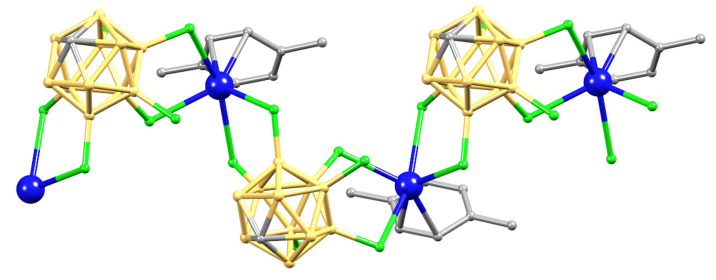

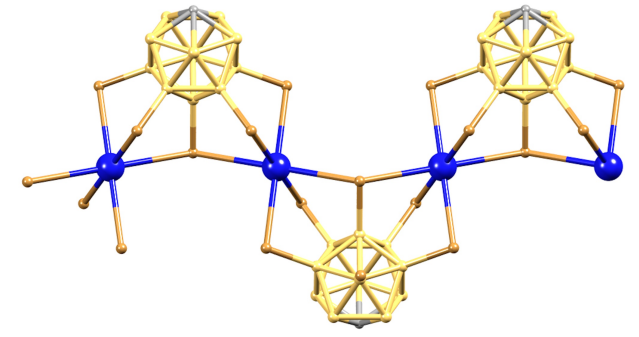

(b)

(c)

Figure 12. Parts of 1D-polymer chains in (a) $\left\{\mathrm{Ag}\left[\mathrm{CB}_{11} \mathrm{H}_{6} \mathrm{I}_{6}\right] \cdot 0.5 \mathrm{C}_{6} \mathrm{H}_{6}\right\}_{n}$ (solvent omitted), (b) $\left\{\mathrm{Ag}\left[\mathrm{CB}_{11} \mathrm{H}_{6} \mathrm{Br}_{6}\right]\right\}_{n}$ and (c) $\left\{\mathrm{Ag}\left[\mathrm{CB}_{11} \mathrm{H}_{6} \mathrm{Cl}_{6}\right] \cdot 1,4-\mathrm{Me}_{2} \mathrm{C}_{6} \mathrm{H}_{4}\right\}_{n}$. Refcodes ROMZIC, ROMZEY and ROMZAU; $\mathrm{H}$ atoms omitted.

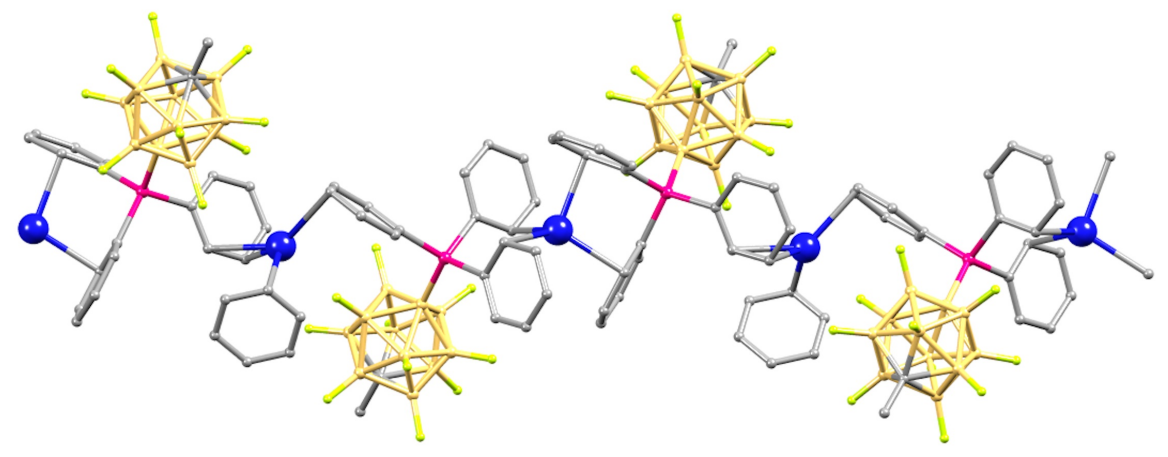

Figure 13. Part of a $1 \mathrm{D}$-chain in the organometallic polymer $\left\{\mathrm{Ag}\left[1-\mathrm{Me}-12-\mathrm{Ph}_{3} \mathrm{Si}-\right.\right.$ $\left.\left.\mathrm{CB}_{11} \mathrm{~F}_{10}\right] \cdot 0.5 \mathrm{C}_{6} \mathrm{H}_{6}\right\}_{n}$. Refcode GIQWIN; H atoms omitted.

Finally, in respect of halogenated clusters, a comment should be made concerning the host-guest interactions in $\left\{\left[\mathrm{K}(\mathrm{CTV})_{2}\right] \cdot 2 \mathrm{CF}_{3} \mathrm{CH}_{2} \mathrm{OH} \cdot \mathrm{CB}_{9} \mathrm{H}_{5} \mathrm{Br}_{5}\right\}_{n}$ and $\left\{[\mathrm{Rb}(\mathrm{CTV})(\mathrm{MeCN})] \cdot \mathrm{CB}_{9} \mathrm{H}_{5} \mathrm{Br}_{5}\right\}_{n}$ (CTV, see Scheme 1$)$. The $\mathrm{K}^{+}$and $\mathrm{Rb}^{+}$ions connect the CTV receptors into a 1D-chain or 2D-net, respectively. In $\left\{\left[\mathrm{K}(\mathrm{CTV})_{2}\right]\left[\mathrm{CB}_{9} \mathrm{H}_{5} \mathrm{Br}_{5}\right] \cdot 2 \mathrm{CF}_{3} \mathrm{CH}_{2} \mathrm{OH}\right\}_{n}$, the carborane clusters act strictly as counterions, and CTV host-guest interactions involve the $\mathrm{CF}_{3} \mathrm{CH}_{2} \mathrm{OH}$ molecules in preference to the $\left[\mathrm{CB}_{9} \mathrm{H}_{5} \mathrm{Br}_{5}\right]^{-}$ions. In $\left\{[\mathrm{Rb}(\mathrm{CTV})(\mathrm{MeCN})]\left[\mathrm{CB}_{9} \mathrm{H}_{5} \mathrm{Br}_{5}\right]\right\}_{n}$, carborane 
anions are more intimately associated with the coordination network by virtue of $\mathrm{Rb}-\mathrm{Br}$ contacts (3.583(1) and 3.745(1) $\AA$ ), but again are not guests within the CTV bowls [25].

\section{Carboxylato- functionalized carboranes}

The incorporation of carborane clusters as linkers in coordination polymers is best realized by introducing metal-binding directly bonded to the cage. $C$-Bonded carboxylic acids are readily introduced, and altering the substitution pattern in the cage (1,2-, 1,7- or 1,12-) provides a variation in vectorial dependence of the linker. Murkin, Hupp and coworkers have been particularly active in this area, generating MOFs of interest for their gas adsorption properties. The first such frameworks were reported in 2007. Reaction of 1,12-( $\left(\mathrm{HO}_{2} \mathrm{C}\right)_{2}-1,12-\mathrm{C}_{2} \mathrm{~B}_{10} \mathrm{H}_{10}$ with $\mathrm{Zn}\left(\mathrm{NO}_{3}\right)_{2} \cdot 6 \mathrm{H}_{2} \mathrm{O}$ in diethylformamide (DEF) under solvothermal conditions gave $\left\{\mathrm{Zn}_{3}\left(\mu_{3}-\mathrm{OH}\right)\left(1,12-\left(\mathrm{O}_{2} \mathrm{C}\right)_{2}-1,12-\mathrm{C}_{2} \mathrm{~B}_{10} \mathrm{H}_{10}\right)_{2.5}(\mathrm{DEF})_{4}\right\}_{n}$ rather than the expected MOF-5 type framework (i.e. one containing $\left\{\mathrm{Zn}_{4} \mathrm{O}\right\}$ nodes). Figure 14 shows that the connectivities in the building blocks in $\left\{\mathrm{Zn}_{3}\left(\mu_{3}-\mathrm{OH}\right)\left(1,12-\left(\mathrm{O}_{2} \mathrm{C}\right)_{2}-1,12\right.\right.$ $\left.\left.\mathrm{C}_{2} \mathrm{~B}_{10} \mathrm{H}_{10}\right)_{2.5}(\mathrm{DEF})_{4}\right\}_{n}$, as well as part of the network with DEF molecules omitted. The $\mathrm{C}_{2} \mathrm{~B}_{10}$-clusters are in two environments: one bridging two $\mathrm{Zn}^{2+}$ ions and one linking two pairs of $\mathrm{Zn}^{2+}$ ions; each triangular $\mathrm{Zn}_{3}$-unit is bridged by a $\mu_{3}$ hydroxido ligand. Coordinated DEF was removed by heating crystals under vacuum at $300{ }^{\circ} \mathrm{C}$, but the structure undergoes an irreversible change, the nature of which has not been crystallographically established. The solvent-free framework exhibits a high $\mathrm{H}_{2}$ uptake at $77 \mathrm{~K}$ [26]. For upscaling of the synthesis, DMF replaced DEF, and powder diffraction data confirmed negligible structural difference between the bulk products. Removal of DMF (under vacuum at 300 ${ }^{\circ} \mathrm{C}$ ) results in shrinking of the pores and the presence of coordinatively unsaturated $\mathrm{Zn}^{2+}$ ions; heating at only $100^{\circ} \mathrm{C}$ removes non-coordinated solvent from the lattice but leaves zinc-coordinated DMF. The DMF-free MOF has been applied to the separation of $\mathrm{CO}_{2}$ and $\mathrm{CH}_{4}$ at $298 \mathrm{~K}, \mathrm{CO}_{2}$ being more strongly adsorbed than $\mathrm{CH}_{4}$ [27]. Cobalt(II) nitrate and acetate react with 1,12-( $\left.\mathrm{HO}_{2} \mathrm{C}\right)_{2}$ 1,12- $\mathrm{C}_{2} \mathrm{~B}_{10} \mathrm{H}_{10}$ under solvothermal conditions (DMF/EtOH or pyridine $/{ }^{\mathrm{n}} \mathrm{BuOH} / \mathrm{H}_{2} \mathrm{O}$, respectively) to give the $3 \mathrm{D}$-frameworks $\left\{\mathrm{Co}_{4}(\mathrm{OH})_{2}(1,12\right.$ $\left.\left.\left(\mathrm{O}_{2} \mathrm{C}\right)_{2}-1,12-\mathrm{C}_{2} \mathrm{~B}_{10} \mathrm{H}_{10}\right)_{3}(\mathrm{DMF})_{2}\right\}_{n}$ (Figure 15) and $\left\{\mathrm{Co}\left(1,12-\left(\mathrm{O}_{2} \mathrm{C}\right)_{2}-1,12-\right.\right.$ 
$\left.\left.\mathrm{C}_{2} \mathrm{~B}_{10} \mathrm{H}_{10}\right)(\mathrm{py})_{2}\left(\mathrm{H}_{2} \mathrm{O}\right)\right\}_{n}$. For the latter, changes to the crystallization method led to agglomerates and a combination of scanning electron microscopy, energydispersive X-ray spectroscopy, thermogravimetic analysis, FT-IR and powder diffraction was used to confirm that both forms of $\left\{\mathrm{Co}\left(1,12-\left(\mathrm{O}_{2} \mathrm{C}\right)_{2}-1,12\right.\right.$ $\left.\left.\mathrm{C}_{2} \mathrm{~B}_{10} \mathrm{H}_{10}\right)(p y)_{2}\left(\mathrm{H}_{2} \mathrm{O}\right)\right\}_{n}$ were structurally similar; they are related in terms of atom connectivity to $\left\{\mathrm{Co}_{4}(\mathrm{OH})_{2}\left(1,12-\left(\mathrm{O}_{2} \mathrm{C}\right)_{2}-1,12-\mathrm{C}_{2} \mathrm{~B}_{10} \mathrm{H}_{10}\right)_{3}(\mathrm{DMF})_{2}\right\}_{n}$ (Figure 15). After thermal treatment to remove solvent, different porosities, crystallinity and surface areas of the three MOFs result in very different adsorption behaviour towards $\mathrm{N}_{2}, \mathrm{CO}_{2}$ and $\mathrm{H}_{2}$ [28]. High selectivities for $\mathrm{CO}_{2}$ over $\mathrm{CH}_{4}$, and for $\mathrm{CO}_{2}$ over $\mathrm{N}_{2}$ have also been demonstrated [29]. The structural variation observed in 2D-networks which combine paddle-wheel $\left\{\mathrm{Cu}_{2}\left(\mu-\mathrm{O}_{2} \mathrm{C}\right)_{4}\right\}$ nodes with 1,12- $\left(\mathrm{O}_{2} \mathrm{C}\right)_{2}-1,12-\mathrm{C}_{2} \mathrm{~B}_{10} \mathrm{H}_{10}$ or 1,7- $\left(\mathrm{O}_{2} \mathrm{C}\right)_{2}-1,12-\mathrm{C}_{2} \mathrm{~B}_{10} \mathrm{H}_{10}$ linkers has been reported by Jin and coworkers [30]; solvent plays a key role in directing the assemblies. These and related lanthanoid-based networks [31] show selective $\mathrm{CO}_{2}$ (over $\mathrm{N}_{2}$ and $\mathrm{CH}_{4}$ ) capture.

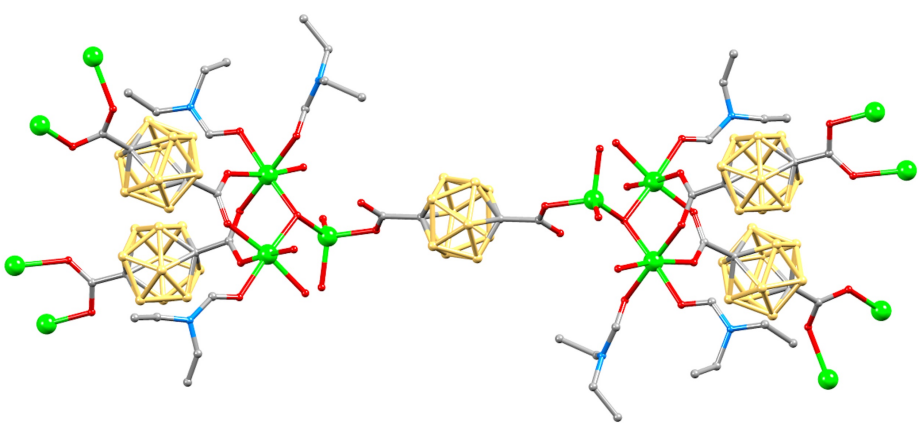

(a)

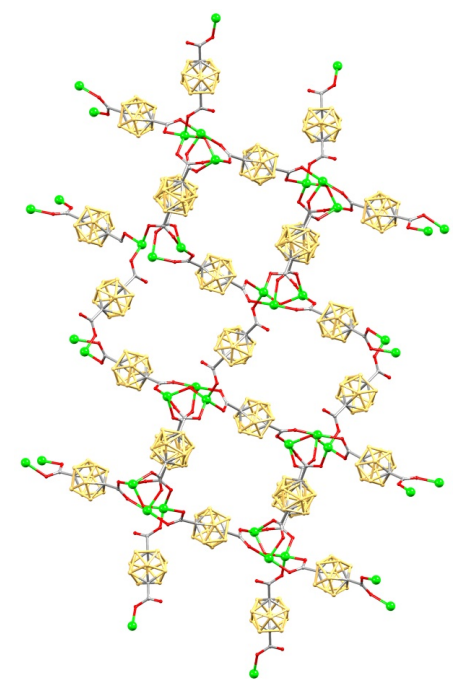

(b)

Figure 14. The MOF $\left\{\mathrm{Zn}_{3}\left(\mu_{3}-\mathrm{OH}\right)\left(1,12-\left(\mathrm{O}_{2} \mathrm{C}\right)_{2}-1,12-\mathrm{C}_{2} \mathrm{~B}_{10} \mathrm{H}_{10}\right)_{2.5}(\mathrm{DEF})_{4}\right\}_{n}$ : (a) connectivities in the building blocks ( $\mathrm{H}$ atoms omitted), and (b) part of the framework viewed down the $b$-axis (H atoms and DEF molecules omitted; refcode VISGOU). 


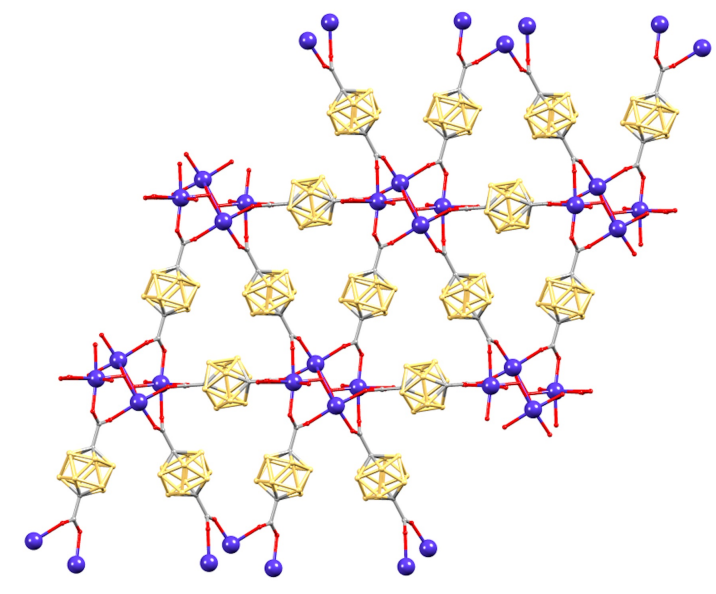

(a)

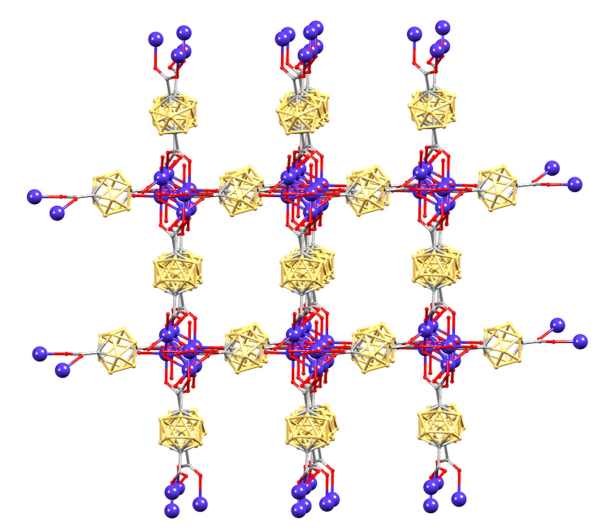

(b)

Figure 15. Two views of part of the lattice in $\left\{\mathrm{Co}_{4}(\mathrm{OH})_{2}\left(1,12-\left(\mathrm{O}_{2} \mathrm{C}\right)_{2}-1,12\right.\right.$ -

$\left.\left.\mathrm{C}_{2} \mathrm{~B}_{10} \mathrm{H}_{10}\right)_{3}(\mathrm{DMF})_{2}\right\}_{n}$ : (a) down the $a$-axis, and (b) showing channels; $\mathrm{H}$ atoms and DMF molecules omitted (refcode WUTKIG).

The use of arene spacers between metal-binding domains (e.g. $\mathrm{CO}_{2}^{-}$ functionalities) is a well-established strategy for increasing pore-sizes in MOFs [32]. The same approach has been adopted in MOFs containing the carborane linkers shown in Scheme 3a [33]. Treatment of these two carboxylic acids with $\mathrm{Zn}\left(\mathrm{NO}_{3}\right)_{2} \cdot 6 \mathrm{H}_{2} \mathrm{O}$ under solvothermal conditions leads to porous frameworks (Figure 16) with different metal nodes; phase purity of the bulk samples was confirmed using powder diffraction. With a phenylene spacer, paddle-wheel $\left\{\mathrm{Zn}_{2}\left(\mu-\mathrm{O}_{2} \mathrm{C}\right)_{4}\right\}$ units connect the carborane linkers (Figure 16b) and coordinated solvent occupies the axial sites of the $\left\{\mathrm{Zn}_{2}\left(\mu-\mathrm{O}_{2} \mathrm{C}\right)_{4}\right\}$ node. However, when the $\mathrm{C}_{2} \mathrm{~B}_{1} 0_{10}$-clusters are directly bonded, $\left\{\mathrm{Zn}_{4}\left(\mu_{3}-\mathrm{OH}\right)_{2}\left(\mu-\mathrm{O}_{2} \mathrm{C}\right)_{4}\left(\mathrm{O}-\mathrm{O}_{2} \mathrm{C}\right)\right\}$ nodes assemble (Figure 16a), with two of the four $\mathrm{Zn}$ atoms bearing two DMF molecules. The combination of monodentate and bridging linkers resembles that observed in $\left\{\mathrm{Zn}_{3}\left(\mu_{3}-\mathrm{OH}\right)\left(1,12-\left(\mathrm{O}_{2} \mathrm{C}\right)_{2}-1,12-\mathrm{C}_{2} \mathrm{~B}_{10} \mathrm{H}_{10}\right)_{2.5}(\mathrm{DEF})_{4}\right\}_{n}$ (Figure 14). Powder diffraction patterns confirm that the frameworks in Figure 16 are retained after thermal activation. A switch in design principle from the ligands in Scheme 3a to that in Scheme 3b provides a 4-connecting linker which reacts with copper(II) nitrate to give a MOF containing 4-connecting $\left\{\mathrm{Cu}_{2}\left(\mu-\mathrm{O}_{2} \mathrm{C}\right)_{4}\right\}$ nodes with coordinated $\mathrm{H}_{2} \mathrm{O}$ in the axial sites of the paddle-wheel units [34]. The assembly (Figure 17) is highly porous with a pore volume of $1.02 \mathrm{~cm}^{3} \mathrm{~g}^{-1}$ and a 
BET surface area of $\approx 2600 \mathrm{~m}^{2} \mathrm{~g}^{-1}$. Both the $\mathrm{H}_{2}$ and $\mathrm{CH}_{4}$ storage capacity of this MOF are extremely high; the absolute $\mathrm{CH}_{4}$ storage capacity is $13.7 \mathrm{mmol} \mathrm{g}^{-1}$ at 65 bar which is 3.3 times lower than the 212 bar pressure needed for comparable $\mathrm{CH}_{4}$ storage in a compressed natural gas tank. These results reveal the highly promising nature of carborane-based MOFs and the design strategies have been extended to longer $\left\{\mathrm{Co}\left(\mathrm{C}_{2} \mathrm{~B}_{9} \mathrm{H}_{11}\right)_{2}\right\}$-centred rigid-rods [35]. However, combinations with paddle-wheel $\left\{\mathrm{Cu}_{2}\left(\mu-\mathrm{O}_{2} \mathrm{C}\right)_{4}\right\}$ nodes do not necessarily give rise to the expected isoreticular MOFs.

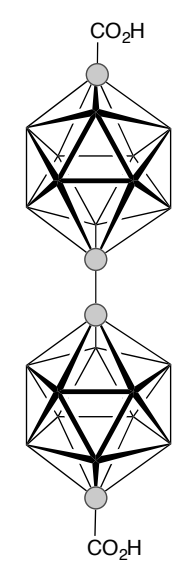

(a)

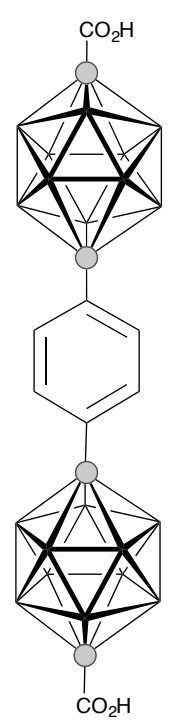

unmarked vertex $=\mathrm{BH} \quad \bigcirc=\mathrm{C}$

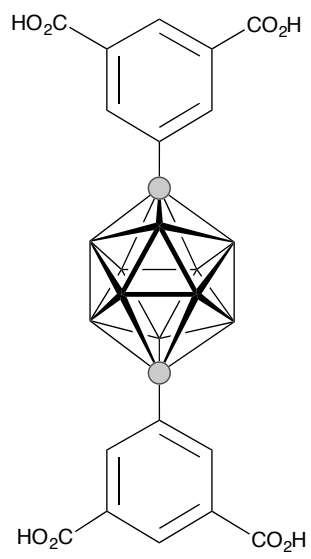

(b)

Scheme 3. (a) Bis-carboxylic acid functionalized carborane-containing linkers for MOFs shown in Figure 16. (b) (a) Tetrakiscarboxylic acid functionalized carborane-containing linker for MOF shown in Figure 17. 


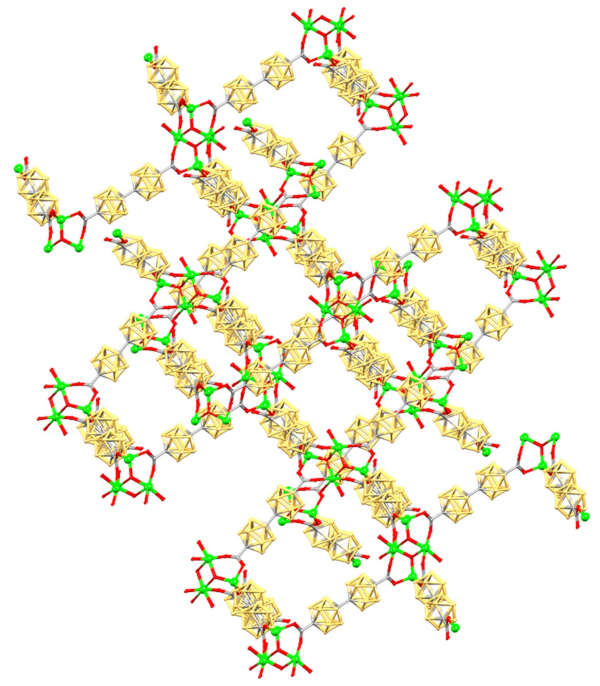

(a)

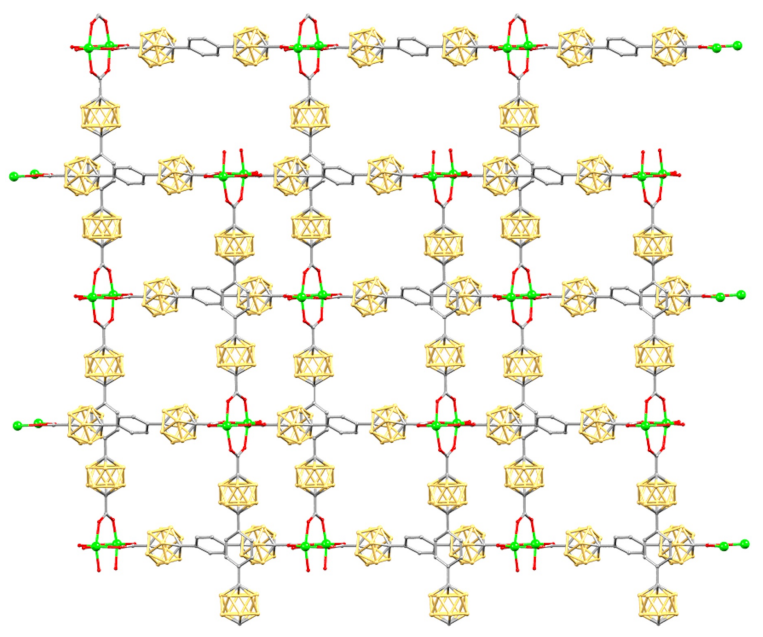

(b)

Figure 16. Part of the 3D-framework formed by combining (a) a bis(carborane) without spacer (Scheme 3a, left) and (b) a bis(carborane) with spacer (Scheme $3 a$, right) with $\mathrm{Zn}\left(\mathrm{NO}_{3}\right)_{2} \cdot 6 \mathrm{H}_{2} \mathrm{O} ; \mathrm{H}$ atoms and coordinated solvent molecules omitted (refcodes ORAQUU and ORARAB).

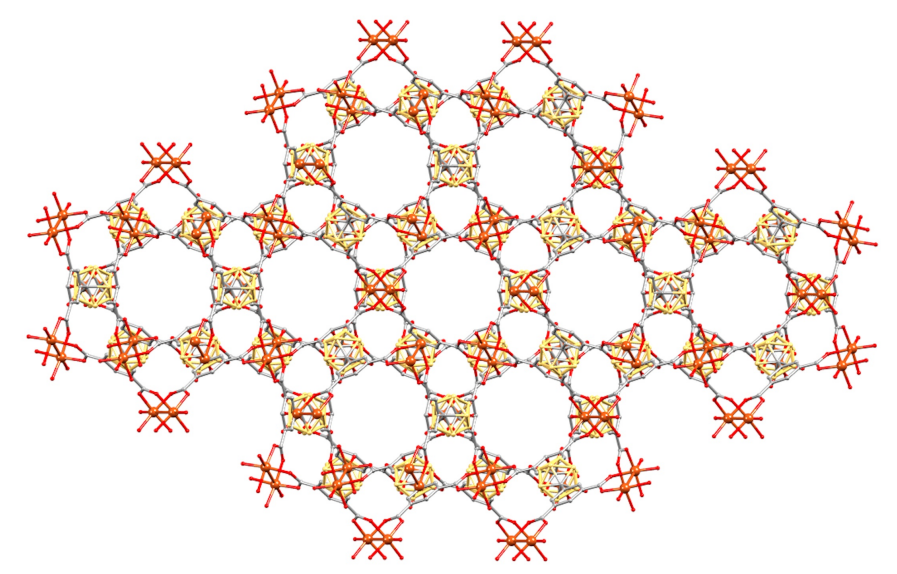

Figure 17. Part of the 3D-framework (viewed down the $c$-axis) formed by combining the linker shown in Scheme $3 \mathrm{~b}$ with $\mathrm{Cu}\left(\mathrm{NO}_{3}\right)_{2} \cdot 2.5 \mathrm{H}_{2} \mathrm{O} ; \mathrm{H}$ atoms omitted (refcode MIZPUI).

By incorporating the carboranylcarboxylato ligand [1-Me-2- $\mathrm{O}_{2} \mathrm{C}-1,2$-closo$\left.\mathrm{C}_{2} \mathrm{~B}_{10} \mathrm{H}_{10}\right]^{-}$in place of a simple $\mathrm{RCO}_{2}-$ ligand in reactions with manganese(II) salts, it has been possible to isolate the water soluble 1D-polymer $\{[\operatorname{Mn}(\mu-$ $\left.\left.\left.\mathrm{H}_{2} \mathrm{O}\right)\left(\mu-1-\mathrm{Me}-2-\mathrm{O}_{2} \mathrm{C}-1,2-\mathrm{C}_{2} \mathrm{~B}_{10} \mathrm{H}_{10}\right)_{2}\right]\right\}_{n}$ (Figure 18). The chains possess a handedness and steric demands of the cluster limit interactions between the 
chains [36]. When exposed to coordinating solvent such as $\mathrm{Et}_{2} \mathrm{O}$, the chain is cleaved into discrete trinuclear units which retain the local structural features of the polymer; coordinated $\mathrm{Et}_{2} \mathrm{O}$ molecules and carboranyl clusters terminate each $\left\{\mathrm{Mn}_{3}\left(\mu-1-\mathrm{Me}-2-\mathrm{O}_{2} \mathrm{C}-1,2-\mathrm{C}_{2} \mathrm{~B}_{10} \mathrm{H}_{10}\right)_{4}\right\}$ unit. In water, the polymer reassembles, making this an unusually clean reversible assembly process. Replacing the CMe cluster units by $\mathrm{CH}$ leads to a related 1D-polymer containing 5-coordinate rather than octahedral Mn(II) centres and this polymer is also cleaved by coordinating solvents. Weak antiferromagnetic coupling is observed between Mn(II) centres along a chain, but chains are spatially remote as a consequence of the bulky cluster domains [37].

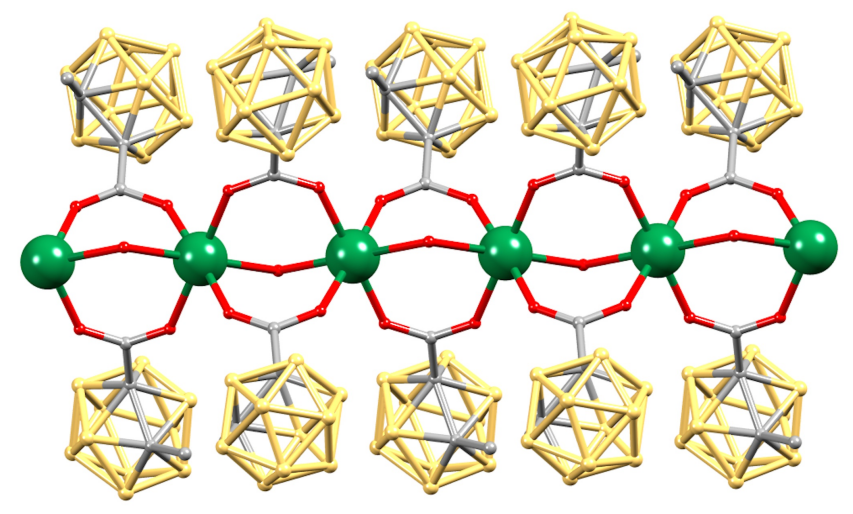

Figure 18. Part of a 1D-polymer chain in $\left\{\left[\mathrm{Mn}\left(\mu-\mathrm{H}_{2} \mathrm{O}\right)\left(\mu-1-\mathrm{Me}-2-\mathrm{O}_{2} \mathrm{C}-1,2-\right.\right.\right.$ $\left.\left.\left.\mathrm{C}_{2} \mathrm{~B}_{10} \mathrm{H}_{10}\right)_{2}\right] \cdot \mathrm{H}_{2} \mathrm{O}\right\}_{n} ; \mathrm{H}$ atoms and $\mathrm{H}_{2} \mathrm{O}$ solvate omitted (refcode PERVIT).

\section{Phosphino-functionalized carboranes}

Despite the fact that 1,2-( $\left.\mathrm{R}_{2} \mathrm{P}\right)_{2}-1,2-\mathrm{C}_{2} \mathrm{~B}_{10} \mathrm{H}_{10}$ derivatives are well established, phosphino-substituted carborane cages remain underexplored in coordination polymer chemistry. Dou and coworkers have reported reactions of $1,2-\left(\mathrm{Ph}_{2} \mathrm{P}\right)_{2}-$ 1,2- $\mathrm{C}_{2} \mathrm{~B}_{10} \mathrm{H}_{10}$ with $\mathrm{HgCl}_{2}$ [38] and 1,2-( $\left.\mathrm{Cy}_{2} \mathrm{P}\right)_{2}-1,2-\mathrm{C}_{2} \mathrm{~B}_{10} \mathrm{H}_{10}$ (Cy = cyclohexyl) with silver salts [39]. These reactions yield either discrete complexes or 1D-polymers supported by chlorido or thiocyanato bridges. The phosphino-functionalized carborane clusters act as chelating ligands and appear innocent in terms of influencing the polymer backbone. Bulk synthesis of $\left\{\left[\mathrm{Hg}_{5}\left(1,2-\left(\mathrm{Ph}_{2} \mathrm{P}\right)_{2}-1,2-\right.\right.\right.$ $\left.\left.\left.\mathrm{C}_{2} \mathrm{~B}_{10} \mathrm{H}_{10}\right)_{2}(\mu-\mathrm{Cl})_{8}\right] \cdot 2 \mathrm{CH}_{2} \mathrm{Cl}_{2}\right\}_{n}$ was carried out in $\mathrm{CH}_{2} \mathrm{Cl}_{2}$ solution at reflux, and single crystals grown from $\mathrm{CH}_{2} \mathrm{Cl}_{2}$ /hexane; the $1 \mathrm{D}$-polymer chain is shown in Figure 19. The varied outcome of these reactions does not yet provide guidance 
as to how phosphino-functionalized carboranes may be used in rational design of coordination polymers.

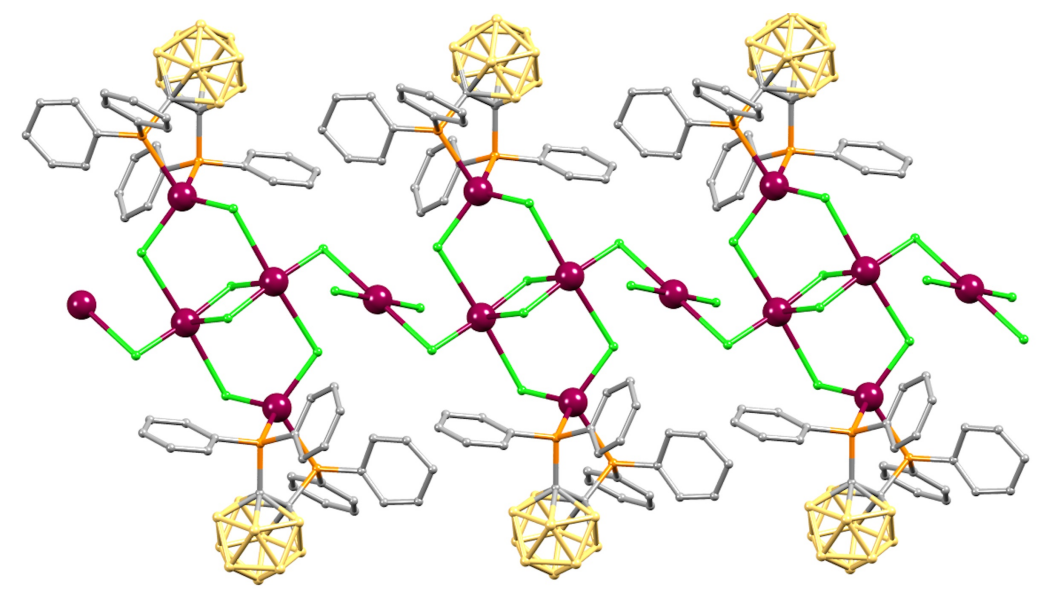

Figure 19. Part of a $1 \mathrm{D}$-chain in $\left\{\left[\mathrm{Hg}_{5}\left(1,2-\left(\mathrm{Ph}_{2} \mathrm{P}\right)_{2}-1,2-\right.\right.\right.$

$\left.\left.\left.\mathrm{C}_{2} \mathrm{~B}_{10} \mathrm{H}_{10}\right)_{2}(\mu-\mathrm{Cl})_{8}\right] \cdot 2 \mathrm{CH}_{2} \mathrm{Cl}_{2}\right\}_{n} ; \mathrm{H}$ atoms and solvent molecules omitted (refcode IPOTUD).

\section{2,2':6',2"-Terpyridinyl-functionalized carboranes}

Molecular aggregation often quenches solution emission of organic lumophores (aggregation-induced quenching, AIQ), but some materials display the reverse phenomenon of aggregation-induced emission (AIE) [40]. Organic polymers comprising alternating $\left\{1,2-\mathrm{C}_{2} \mathrm{~B}_{10}\right\}$ and $\left\{p-\mathrm{C}_{6} \mathrm{H}_{4} \mathrm{C} \equiv \mathrm{CC}_{6} \mathrm{H}_{4}\right\}$ units exhibit AIE, and based on these observations, Kokado and Chujo have designed the ligand in Scheme 4 which binds $\mathrm{Zn}^{2+}$ to give a $1 \mathrm{D}$-coordination polymer $[\mathrm{ZnL}]_{n^{2 n+}}$ containing $\left\{\mathrm{Zn}(\operatorname{tpy})_{2}\right\}$ domains. Aggregation of ligand L (Scheme 4) occurs on changing the solvent from $\mathrm{CHCl}_{3} / \mathrm{MeOH}$ to THF/H$/ \mathrm{H}_{2} \mathrm{O}$ with an $\mathrm{AIE}$ at $509 \mathrm{~nm}$. The formation of the zinc(II) coordination polymer switches on a pale blue emission which originates from a intra-ligand charge transfer (ILCT) [41]. 


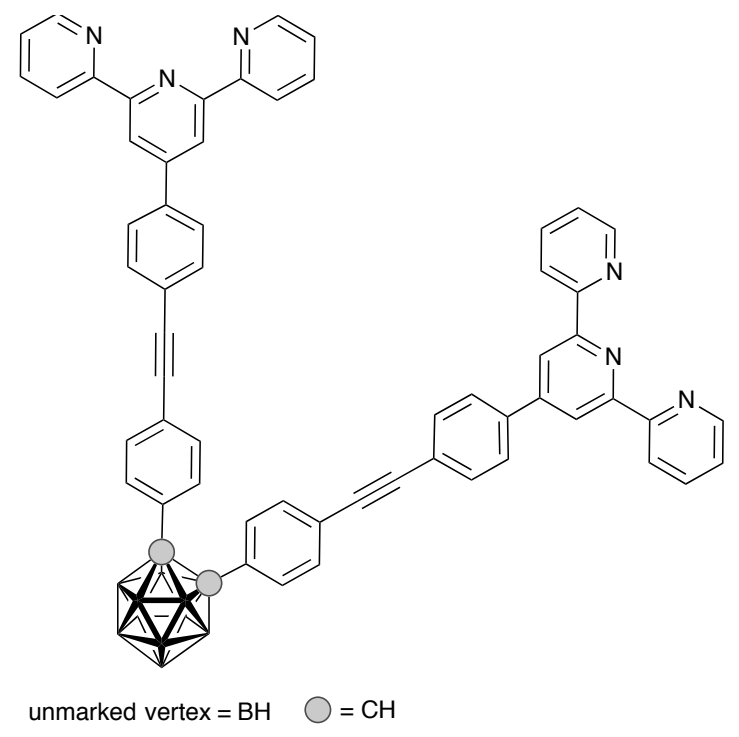

Scheme 4. Structure of the ditopic ligand L which binds zinc(II) to give a 1Dcoordination polymer.

\section{Final comments}

This review has demonstrated a variety of ways in which carborane clusters have been used in the assembly of 1D-coordination polymers, and 2D- and 3Dnetworks. In many of these, the carbabornae cluster is present either as a guest, counterion or peripheral group, and the extent to which the clusters template the assembly is undetermined. However, it is clear that the steric requirements of carborane cages may be applied to tune structures and properties, even if the cage is not intimately involved in the backbone of the assembly. A rich chemistry has been developed in which carborane cages are incorporated into the linkers in MOFs, with design strategies developed for rigid arene-based struts being modified to $\mathrm{C}_{2} \mathrm{~B}_{10}$-cages which are dimensionally comparable to $\mathrm{C}_{6}$-rings. Functionalization of carborane clusters with metal-binding carboxylato or $2,2^{\prime}: 6$ ',2"'-terpyridinyl domains has been used to introduce $\mathrm{C}_{2} \mathrm{~B}_{10}$-cages into the backbones of coordination polymers. This area is ripe for development, as is the application of bis(phosphino)-functionalized carboranes.

\section{References}

1 R. N. Grimes, Dalton Trans. (2015) DOI: 10.1039/C5DT00231A. 
2 K. Biradha, A. Ramanan, J. J. Vittal, Cryst. Growth Des. 9 (2009), 2969; S. R. Batten, N. R. Champness, X.-M. Chen, J. Garcia-Martinez, S. Kitagawa, L. Öhrström, M. O'Keeffe, M. P. Suh, J. Reedijk, CrystEngComm 14 (2012) 3001.

3 B. P. Dash, R. Satapathy, J. A. Maguire, N. S. Hosmane, New J. Chem. 35 (2011) 1955.

4 F. H. Allen, Acta Crystallogr., Sect. B 58 (2002) 380.

5 I. J. Bruno, J. C. Cole, P. R. Edgington, M. Kessler, C. F. Macrae, P. McCabe, J. Pearson, R. Taylor, Acta Crystallogr., Sect. B 58 (2002) 389.

6 M. J. Hardie, P. D. Godfrey, C. L. Raston, Chem. Eur. J. 5 (1999) 1828.

7 M. J. Hardie, C. L. Raston, Cryst. Growth Design 1 (2001) 53.

8 C. Carruthers, J. Fisher, L. P. Harding, M. J. Hardie, Dalton Trans. 39 (2010) 355.

9 M. J. Hardie, C. J. Sumby, Inorg. Chem. 43 (2004) 6872.

10 S. R. Batten, N. R. Champness, X.-M. Chen, J. Garcia-Martinez, S. Kitagawa, L. Öhrström, M. O’Keeffe, M. P. Suh, J. Reedijk, Pure Appl. Chem. 85 (2013) 1715.

11 M. J. Hardie, J. Chem. Cryst. 37 (2007) 69.

12 M. Besora, A. Lledós, Structure and Bonding 130 (2008) 149.

13 N. J. Patmore, J. W. Steed, A. S. Weller, Chem. Commun. (2000) 1055.

14 K. Shelly, D. C. Finster, Y. J. Lee, W. R. Scheidt, C. A. Reed, J. Am. Chem. Soc. 107 (1985) 5955.

15 O. Volkov, C. Hu, P. Paetzold, Z. Anorg. Allg. Chem. 631 (2005) 1107.

16 A. Westcott, N. Whitford, M. J. Hardie, Inorg. Chem. 43 (2004) 3663.

17 L. Cunha-Silva, M. J. Hardie, CrystEngComm 14 (2012) 3367.

18 L. Cunha-Silva, R. Ahmad, M. J. Hardie, Aust. J. Chem. 59 (2006) 40.

19 L. Cunha-Silva, M. J. Carr, J. D. Kennedy, M. J. Hardie, Cryst. Growth Des. 13 (2013) 3162.

20 L. Cunha-Silva, R. Ahmad, M. J. Carr, A. Franken, J. D. Kennedy, M. J. Hardie, Cryst. Growth Des. 7 (2007) 658.

21 Z. Wei, B.-M. Wu, T. C. W. Mak, J. Manning, C. A. Reed, J. Chem. Soc., Dalton Trans. (1997) 1213. 
22 Y. Kobayashi, A. A. Popov, S. M. Miller, O. P. Anderson, S. H. Strauss, Inorg. Chem. 46 (2007) 8505.

23 S. V. Ivanov, S. M. Miller, O. P. Anderson, S. H. Strauss, Cryst. Growth Des. 4 (2004) 249.

24 J. H. Wright II, G. W. Mueck, F. S. Tham, C. A. Reed, Organometallics 29 (2010) 4066.

25 R. Ahmad, M. J. Hardie, New J. Chem. 28 (2004) 1315.

26 O. K. Farha, A. M. Spokoyny, K. L. Mulfort, M. F. Hawthorne, C. A. Mirkin, J. T. Hupp, J. Am. Chem. Soc. 129 (2007) 12680.

27 Y.-S. Bae, O. K. Farha, A. M. Spokoyny, C. A. Mirkin, J. T. Hupp, R. Q. Snurr, Chem. Commun. (2008) 4135.

28 O. K. Farha, A. M. Spokoyny, K. L. Mulfort, S. Galli, J. T. Hupp, C. A. Mirkin, Small 5 (2009) 1727.

29 Y.-S. Bae, A. M. Spokoyny, O. K. Farha, R. Q. Snurr, J. T. Hupp, C. A. Mirkin, Chem. Commun. 46 (2010) 3478.

30 S.-L. Huang, L.-H. Weng, G.-X. Jin, Dalton Trans. 41 (2012) 11657.

31 S.-L. Huang, Y.-J. Lin, W.-B. Yu, G.-X. Jin, ChemPlusChem 77 (2012) 141.

32 See for example: C. Janiak, J. K. Vieth, New J. Chem. 34 (2010) 2366.

33 A. M. Spokoyny, O. K. Farha, K. L. Mulfort, J. T. Hupp, C. A. Mirkin, Inorg. Chim. Acta 364 (2010) 266.

34 R. D. Kennedy, V. Krungleviciute, D. J. Clingerman, J. E. Mondloch, Y. Peng, C. E. Wilmer, A. A. Sargeant, R. Q. Snurr, J. T. Hupp, T. Yildrim, O. K. Farha, C. A. Mirkin, Chem. Mater. 25 (2013) 3539.

35 R. D. Kennedy, D. J. Clingerman, W. Morris, C. E. Wilmer, A. A. Sargeant, C. L. Stern, M. O'Keeffe, R. Q. Snurr, J. T. Hupp, O. K. Farha, C. A. Mirkin, Cryst. Growth Des. 14 (2014) 1324.

36 M. Fontanet, M. Rodríguez, I. Romero, X. Fontrodona, F. Teixidor, C. Viñas, N. Aliaga-Alcalde, P. Matějíček, Dalton Trans. 42 (2014) 7838.

37 M. Fontanet, M. Rodríguez, X. Fontrodona, I. Romero, F. Teixidor, C. Viñas, N. Aliaga-Alcalde, P. Matějíček, Chem. Eur. J. 20 (2014) 13993.

38 L. Kong, D. Zhang, F. Su, J. Lu, D. Li, J. Dou, Inorg. Chim. Acta 370 (2011) 1. 
39 L.-G. Yang, C.-C. Zhu, D.-P. Zhang, D.-C. Li, D.-Q. Wang, J.-M. Dou, Polyhedron 30 (2011) 1469.

40 Y. Hong, J. W. Y. Lam, B. Z. Tang, Chem. Soc. Rev. 40 (2011) 5361.

41 K. Kokado, Y. Chujo, Dalton Trans. 40 (2011) 1919. 